NBER WORKING PAPER SERIES

\title{
CROSSOVER INVENTIONS AND KNOWLEDGE DIFFUSION OF GENERAL PURPOSE TECHNOLOGIES? EVIDENCE FROM THE ELECTRICAL TECHNOLOGY
}

\author{
Shih-tse Lo \\ Dhanoos Sutthiphisal \\ Working Paper 14043 \\ http://www.nber.org/papers/w14043
NATIONAL BUREAU OF ECONOMIC RESEARCH
1050 Massachusetts Avenue
Cambridge, MA 02138

May 2008

We are very grateful to the late Kenneth Sokoloff for his constant encouragement. We have also benefited from comments offered by Daniel Ackerberg, Francisco Alvarez-Cuadrado, Leah Brooks, Jennifer Hunt, Naomi Lamoreaux, Mary MacKinnon, Jean-Laurent Rosenthal, and participants at the BHC, CEA Meetings, CNEH Conference, NBER Summer Institute, McGill, and UCLA. We would like to thank Carolina Corral and Jinyuan He for their excellent research assistance. Finally, Sutthiphisal acknowledges financial support from Fonds québécois de la recherche sur la société et la culture (FQRSC). The views expressed herein are those of the author(s) and do not necessarily reflect the views of the National Bureau of Economic Research.

NBER working papers are circulated for discussion and comment purposes. They have not been peerreviewed or been subject to the review by the NBER Board of Directors that accompanies official NBER publications.

(C) 2008 by Shih-tse Lo and Dhanoos Sutthiphisal. All rights reserved. Short sections of text, not to exceed two paragraphs, may be quoted without explicit permission provided that full credit, including (C) notice, is given to the source. 
Crossover Inventions And Knowledge Diffusion Of General Purpose Technologies: Evidence

From The Electrical Technology

Shih-tse Lo and Dhanoos Sutthiphisal

NBER Working Paper No. 14043

May 2008

JEL No. N0,O3

\begin{abstract}
Scholars have long noted the significant impact of general purpose technologies (GPTs) on the economy. However, limited attention has been paid to exploring how they are employed to generate inventions in downstream sectors (crossover inventions), and what factors may facilitate such diffusion. We study these issues by examining the introduction of one of the widely regarded GPTs - electrical technology - in the late 19th century U.S. We find that knowledge spillovers between industries (inter-industry spillovers and learning-by-using) had little influence on the geography of crossover inventions as well as the speed and productivity of inventors at making them. Instead, appropriate human capital and an environment promoting inventions in general played a more important role.
\end{abstract}

Shih-tse Lo

McGill University

Department of Economics

855 Sherbrooke Street West

Montreal, Quebec H3A, 2T7

CANADA

shih-tse.lo@mcgill.ca

Dhanoos Sutthiphisal

McGill University

Department of Economics

855 Sherbrooke Street West

Montreal, Quebec H3A, 2T7

CANADA

and NBER

dhanoos.sutthiphisal@mcgill.ca 


\section{INTRODUCTION}

Technological progress has long been recognized as a crucial source of economic growth. Throughout history, this progress has consisted of a handful of important technological breakthroughs and numerous incremental technological improvements. These key technological breakthroughs are often referred to in the literature as General Purpose Technologies (GPTs). ${ }^{1}$ Examples of such breakthroughs are steam engines, electricity and information technology (IT). These GPTs have been widely adopted in a broad range of industries as well as spurred inventive activity in the downstream sectors.

Given the importance of GPTs to the overall economic activity, a number of studies have investigated how such technologies were adopted and what their effects were. For example, Atack et al. (1980) explore how steam engines were adopted as a new power source in manufacturing. Crafts (2004) and Atack et al. (2008) examine the effects of steam engines on productivity growth. Rosenberg and Trajtenberg (2004) and Kim (2005) investigate the impact of steam engines on urbanization. Krueger (1993) and Goldin and Katz (1998) study how computers and electricity at workplace affected the labor market. However, limited attention has been paid to exploring how GPTs spur inventive activity in downstream sectors as well as to identifying mechanisms that facilitate the diffusion of GPTs to other industries. ${ }^{2}$ An understanding of such mechanisms may help us better allocate resources to promote more rapid generation and

\footnotetext{
${ }^{1}$ See, for example, Bresnahan and Trajtenberg (1995) and Lipsey et al. (2006).

2 Prior work on the diffusion of new technological knowledge largely focuses on knowledge transfer within a single industry, for example, Brittain (1974) and Hughes (1983). Key exceptions to this strand of research are Rosenberg (1963) and Thomson (1991). They argue that the mechanical technology of the First Industrial Revolution in the U.S. was spread through the tools and machinery sector, and there were knowledge spillovers between industries. However, the mechanisms underlying the diffusion of mechanical technology may differ from those for newer, and more scientifically based technologies.
} 
diffusion of new technological knowledge. ${ }^{3}$ This issue is also a growing concern for developing countries. In recent years, countries such as China and Malaysia have attempted to attract high-tech firms and their R\&D facilities from developed countries, hoping that such relocation will generate knowledge spillovers to other industries. ${ }^{4}$ However, to know whether such a policy will be successful, and more generally, to design policies that improve the diffusion of GPTs, we need to understand how they diffuse and what governs such process.

Our analysis, therefore, explores the introduction of an important technological discovery - electrical technology - in the late 19th century and seeks to address how an understanding of electricity was acquired and used to generate inventions in other industries. (Henceforth, such inventions are referred to as crossover inventions.) We examine a number of factors, which may facilitate the diffusion of electrical technology into inventive activity in various industries.

One of the factors is knowledge spillovers. They are often highlighted in the literature as a key factor in technology diffusion and thereby economic growth (Romer, 1986 and Lucas, 1988). There are two types of spillovers. One occurs within a single industry and the other happens between industries. Knowledge spillovers between industries, as pointed out by Jacobs (1969) and Glaeser et al. (1992), can be of more importance to the generation of new ideas than those taking place within an industry. Unfortunately, much of prior empirical effort has focused on assessing the effects of

\footnotetext{
${ }^{3}$ The term "diffusion" has been used in various contexts. For example, Rose and Joskow (1990) regard the usage or adoption of new technology as technological diffusion. In this article, we denote "diffusion" as the transfer of new technical knowledge through creating an invention, which include modifying or retooling existing machinery and production methods and may precede the adoption.

${ }^{4}$ For example, www.msc.com.my indicates that Malaysia established the Multimedia Super Corridor (MSC) in 1996, hoping to become an international hub for the information and communication technologies sector, and eventually an inventive and innovative economy.
} 
spillovers within an industry. ${ }^{5}$ Little progress has been made on examining the impact of knowledge spillovers that occur between industries.

Consequently, in our investigation of GPT diffusion we pay special attention to knowledge spillovers that occur between industries. Such spillovers can take on the forms of inter-industry spillovers (interaction between inventors of different industries) as well as learning-by-using. We assess the contribution of these spillovers against that of much broader factors, such as human capital and a favorable economic environment for invention in general.

We study the impact of these factors on crossover inventive activity at both the aggregate and individual levels. At the aggregate level, we compare the location of these factors with that of crossover inventive activity. The logic behind such a geographic comparison is that individuals who can benefit from these factors, and thereby likely create crossover inventions, are those who reside in areas where such factors are prevalent. Moreover, for the chosen electrical technology, these factors, to our advantage, exhibited different geographic patterns from each other. The geographic analysis thus allows us to identify factors that enhance the ability of an area's general population in generating crossover inventions.

The individual analysis, on the other hand, closely follows the people who succeeded in creating crossover inventions over their lives. We explore the biographic information of these crossover inventors. Such information offers an opportunity to study crossover inventors over their entire lifespan (for example, their educational background and career choices), and allows us to compare their background with that of other types of inventors. This type of analysis can only be performed with historical data,

\footnotetext{
${ }^{5}$ See, for example, Saxenian (1994), and Adams and Jaffe (1996).
} 
as detailed biographical information on contemporary inventors is rarely available. We also investigate how the factors of interest, such as inter-industry spillovers and human capital, affect the speed and productivity of crossover inventors at making crossover inventions.

The two different approaches together help us better gauge the effects of these factors on crossover inventive activity. The individual analysis, which examines each crossover inventor closely, allows one to draw direct inference about the factors that change his ability in making crossover inventions while controlling for other factors that may be confounded in the aggregate analysis, such as geographic relocation. However, by focusing on these individuals who did successfully make crossover inventions, the individual approach suffers from sample selection. The aggregate analysis gets around this as it includes all regions, even regions that had no crossover inventions.

To carry out our analysis, in addition to utilizing information reported by the U.S. census, we constructed a unique dataset from U.S. patent records, census manuscripts, city directories, newspaper obituaries, as well as family and local histories. The dataset contains detailed information on crossover inventions and biographical information about crossover inventors over their career (for example, their educational background and the pattern of their patenting behaviors). Such micro-level information provides us a sense of how an inventor acquired the knowledge of the electrical technology and how he applied it to crossover inventive activity over his inventive career.

We find that the impact of inter-industry spillovers, although positive, appeared small. Regions where inter-industry spillovers were expected to be prevalent did not observe a correspondingly high level of crossover inventive activity. Nor did such 
mechanism considerably shorten the time for an inventor to create his first crossover invention and raise his productivity at making them. The evidence also reveals that learning-by-using was of little importance in the diffusion of the electrical technology. In contrast, conditions conducive to inventive activity in general and human capital formation played a critical role. Not only did they enhance the population's ability to create crossover inventions, but they raised the speed and productivity of inventors at making crossover inventions considerably. These results suggest that the importance of knowledge spillovers (at least between industries) may be overstated, whereas investment in human capital may be under-appreciated in the knowledge diffusion literature. Also, if the experience of the introduction of electrical technology can be generalized to the spread of the modern GPTs such as IT, the recent policies of developing countries that try to attract firms to relocate their $R \& D$ facilities may not bring about increased rates of inventions in these economies unless they have first established a favorable environment for inventive activity in general and accumulate sufficient levels of general human capital.

\section{FRAMEWORK}

\section{A. Factors that May Facilitate Crossover Inventive Activity}

Knowledge spillovers that occur between industries may help the diffusion of a GPT and facilitate crossover inventive activity. Two types of knowledge spillovers between industries are of particular interest.

Inter-industry Spillovers. These occur when inventors in different industries interact and exchange knowledge. Close physical proximity of individuals working in the field where the important technology breakthrough takes place (the “core” industry) and 
individuals in other industries provides ample opportunities to communicate and exchange information. This allows inventors in downstream industries to acquire the new technical knowledge of the GPT and exploit it in their own fields. Likewise, inventors in the core industry may learn about potential applications of the new technology in other fields. We refer to this sort of spillovers between inventors as inter-industry spillovers.

Learning-by-using. Rosenberg (1982) argues that firms can learn from their use of machinery in production and such a use leads to cost reduction, efficiency enhancement and further improvements of the machinery. ${ }^{6}$ In the context of GPT diffusion, an individual who works in an industry which utilizes the new GPT is more likely to invest the time and effort to understand its scientific foundations and recognize its potential in various fields, and thereby may be more likely to create crossover inventions. This may also be true for individuals who live in an area where the technology is introduced relatively early, whatever industry they work in. These individuals have an advantage in learning and applying the potential of such a newly developed technology over others residing where the GPT is introduced much later.

The two types of knowledge spillovers between industries (inter-industry spillovers and learning-by-using) are potential factors that disseminate the specific knowledge of a GPT. However, there are other factors that may not only encourage knowledge transfer of the GPT, but also enhance the ability of population to carry out inventive activity in general. Such broader factors can help the economy respond to the arrival of the GPT more rapidly.

\footnotetext{
${ }^{6}$ The concept of learning-by-using is analogous to learning-by-doing that described in several studies such as Arrow (1962) and Irwin and Klenow (1994). There are also other forms of learning. See, for example, Malerba (1992).
} 
Human capital. An important factor is human capital. Previous work such as Wozniak (1987) and Sutthiphisal (2006) has shown that human capital plays a central role in the spread of technology and the generation of new technical knowledge. We would expect human capital to have a positive impact on the diffusion of a GPT into inventive activity in various industries. The scientific principles behind the GPT may be taught in learning institutions, so their attendees can obtain knowledge of the GPT from their studies and later apply it to various fields. In addition to direct education about the newly developed technology, learning institutions often transfer knowledge complementary to the new technology. Chemistry, physics, metallurgy and other types of engineering, for instance, are complementary to the field of electrical technology. Individuals trained or educated in these complementary fields may have an advantage in understanding the newly developed electrical technology. As a result, learning institutions, even without instructing the scientific principles behind the GPT, may raise the level of general human capital and indirectly make it easier for a society to absorb the new knowledge.

Conditions that promote inventive activity in general. The factors we have discussed thus far focus on how the technologically creative acquire knowledge of a newly developed technology. These factors likely help inventors learn about the GPT and realize its potential. However, in order for inventors to physically carry out inventive activity, mechanisms and economic conditions that help inventors extract and secure returns from their creations can be crucial. For example, Khan (2005) suggests that a well designed patent and copyright system was the key to the rise of the American creativeness between 1790 and 1920. Lamoreaux and Sokoloff (1999) stress the role of 
market institutions that promoted trade and investment in technology in stimulating inventive activity. Consequently, these conditions that promote inventive activity in general, not necessarily specific to the GPT in question, can be of more importance to crossover inventive activity.

\section{B. Assessing the Impact of the Factors}

To examine how these factors affect the assimilation of GPTs into inventive activity in various industries (and thereby the generation of crossover inventions), we focus on the introduction of electrical technology in the U.S. during the late 19th century. Electrical technology has been widely acknowledged as one of the most important technological breakthroughs. Its introduction brought about technological advances in a vast array of existing industries. Moreover, electrical technology was highly complex and abstract in nature. Electricity and electrical products also spread quickly to not only in the manufacturing sector but in the service sector as well as households. ${ }^{7}$ In many ways, electrical technology exhibits characteristics that mirror GPTs of the present day such as IT.

Another advantage of examining electrical technology is that it is easier to empirically identify inventive activity that employed such technology than is the case for IT or other modern GPTs. For example, the description of an invention employing the electrical technology is very likely to include the words "electric," "electricity," or “electro”. In contrast, an IT can be described in many ways such as a circuit, signal process, or even an algorithm. Furthermore, by exploring the arrival of electrical

${ }^{7}$ Although Moser and Nicholas (2004) argue that the electrical technology does not meet the theoretical requirements of a GPT, others such as Bresnahan and Trajtenberg (1995) and Jovanovic and Rousseau (2005) consider the technology as a seminal example of a GPT. Given its broad impact on other industries, electrical technology is undeniably one of the most important technologies in the modern era. 
technology in the U.S. during the late 19th century as opposed to a contemporary GPT, we can benefit from the rich biographical information on individuals contained in U.S. historical records such as census manuscripts and city directories. The biographical information offers an opportunity to study crossover inventors over their entire lifespan (for example, their educational background and career choices), but similar information on contemporary inventors is rarely available.

More importantly, the electrical technology posits a unique advantage in assessing the effects of the factors, especially inter-industry spillovers. During the early development of the electrical industry, the location of core electrical inventive activity was very different from that of inventive activity in other industries as well as from that of core electrical manufacturing. ${ }^{8}$ Such geographic disparities make it possible to gauge the relative influence of the factors on the diffusion of electrical technology into other industries, by comparing geographic distribution of crossover inventive activity with those of these factors (or their measurable proxies). The circumstance surrounding the electrical technology was quite analogous to that of the IT industries. While both California’s Silicon Valley and Massachusetts' Route 128 are well known for their high concentration of IT firms, inventive activity as well as production facilities of other industries that may employ and benefit from IT products and inventions in IT fields is largely in other parts of the country. As a result, the experience from the electrical technology may shed some light on the diffusion of IT and other modern GPTs.

Consequently, we gauge the impact of the factors by examining whether, and to what extent, the location of crossover inventive activity can be explained by the

\footnotetext{
${ }^{8}$ See Sutthiphisal (2006) for the location of basic electrical inventive activity and Lamoreaux and Sokoloff (1999) for the location of overall inventive activity. Also, Appendix 1 provides a brief background on early development of the electrical industries.
} 
geographic clustering of these factors. For example, inter-industry spillovers are likely more pronounced in areas where core inventors (and inventions) are highly concentrated since potential inventors in other fields have more opportunities to interact with individuals in the core field and thus gain from inter-industry spillovers. If inter-industry spillovers play the most important role, the geographic pattern of crossover inventions should mirror that of core inventions. ${ }^{9}$ The same argument can be applied to other factors that may foster crossover inventive activity. Potential inventors living in areas with high rates of utilization or adoption of the electrical technology are more likely to have used the new technology, and therefore understand its potential and benefit from learning-byusing. The geographic distribution of crossover inventive activity may, thus, exhibit a similar pattern to that of electric utilization. Also, residents of areas abundant with individuals educated in the fields directly associated with (or complementary to) the new technology more likely have the appropriate human capital to adapt the new technology. Hence, the location of crossover inventive activity may display a high correlation with the location of individuals with appropriate human capital. Finally, areas where conditions conducive to inventive activity in general are more prevalent should exhibit more inventions overall, as inventors likely exploit such a favorable environment. If these conditions are central to crossover inventive activity, as compared to inter-industry spillovers and learning-by-using and appropriate human capital, it is likely that crossover inventions occur where inventive activity is intense overall.

${ }^{9}$ Jaffe and Trajtenberg (1999) trace spillovers from patent citations and find that inventors are less inclined to cite prior arts that are not in the same field as their own inventions. Thus, the use of patent citations to measure spillovers may underestimate the impact of inter-industry spillovers. Moreover, a study of patent citations alone is not sufficient to identify other factors, and assess their relative importance on promoting crossover inventive activity. 
The geographic comparison between crossover inventive activity and the factors of interest will reveal the extent to which these factors boost the general capacity of the economy (or a region) to absorb the electrical technology, diffuse it and produce crossover inventions. Such a study, therefore, helps us identify key mechanisms at the aggregate level. To further our understanding of the process that governs the diffusion of electrical technology, we also explore the effects of these factors at a more individual level. We undertake a close examination of those who did succeed in making crossover inventions - crossover inventors. Although they accounted for a very small segment of the population, their existence was vital to the implementation of the electrical technology into various downstream industries. We probe into the biographical characteristics of these crossover inventors such as education and training background, and compare them with those of inventors who made other types of inventions. We also gauge the impact of the factors by testing whether living where these factors were prevalent or clustered affected how soon a crossover inventor started producing crossover inventions as well as how many crossover inventions he made over his career.

Such an individual approach complements the previous geographic investigation. The individual analysis can better distinguish the process of technical change when a hundred inventors are granted one patent over their lifetime from that when an inventor patents one hundred times. Moreover, by examining each inventor closely over his lifetime, we can draw inference about the factors that change his ability in making crossover inventions while controlling for other factors that may be confounded in the geographic analysis. For example, relocation from Boise, Idaho to Chicago, Illinois may enhance the inventor's inventiveness. Following each individual inventor allows us to 
alleviate complication due to relocation, and to concentrate on the factors that may facilitate the diffusion of the technology. Such an individual investigation, nonetheless, suffers from sample selection, as it focuses only on individuals who successfully made crossover inventions. Excluding those who did not create any crossover inventions, the individual analysis cannot completely reveal how the factors can affect the entire population's ability to generate crossover inventions. The geographic analysis, on the other hand, studies all regions including those that failed to produce any crossover invention. It is necessary to employ both approaches, and they together help us better assess the effects of these factors on the diffusion of electrical technology into inventive activity in various industries.

\section{DATA}

We use patent statistics to gauge inventive activity. ${ }^{10}$ We construct cross-sections of (utility) patents employing electrical technology that were granted in 1890 and 1910 by the United States Patent and Trademark Office (USPTO). ${ }^{11}$ To identify whether or not a patent employed electricity, we exploit information in the patent grant document: abstract, specification, claims (and drawing) that describe how an invention can be constructed or used. We first obtain a tentative list of all utility patents granted in the

${ }^{10}$ For studies that also use patent statistics, see, for example, Schmookler (1966) and Sokoloff (1988). Griliches (1990) provides insights into why patent statistics offer a reasonable indicator of inventive activity. In addition, technical improvements in the core electrical industry were likely patented because it was difficult to keep them secret.

${ }^{11}$ The logic behind the two years chosen for this study is twofold. First, there are few data on the electrical industries before 1890. For example, there were only 18 core electrical patents granted in 1870 as shown in Sutthiphisal (2006). Nor did the U.S. census of manufacturing report electricity production or power usage before 1890. Second, these years allow for comparisons with other samples. 
cross-section years listed in LexisNexis (U.S. Patents) on-line database by using “electric” as the key word for search inquiry. This list contains a total of 3,414 patents. ${ }^{12}$

Our tentative list includes inventions such as electric batteries and dynamos that are advances in the core electrical industry and inventions such as electric lighting and transportation that are widely regarded as the driving force behind the development of electrical technology (see Appendices 1 and 2). Given the fact that USPTO classifies patents by their functional use and that no classification system is based on the technology underlying or being employed by each invention, we read through the patent grant documents of the 3,414 patents in our list in order to identify and include only the crossover inventions. As shown in Table 1, there are 457 patents classified as crossover inventions in 1890 and 856 in 1910. These inventions are applications of electrical technology in various fields. An electric stop motion for warping machines, an electric razor, and an electric safety device for slaughtering animals are a few examples of such inventions. Out of these 1,313 crossover patents, 1,120 were granted to U.S. residents. ${ }^{13}$

For the U.S. based crossover inventions, we obtain the name and address of patentees and their assignees (individuals or firms who purchased the ownership of the inventions before the dates that the patents were granted) from the patent records. We then collect similar information for all patents each patentee received over his career

${ }^{12}$ LexisNexis uses imaging technology to transform all USPTO's patent grant documents into a searchable text database. Unfortunately, the imaging technology is not perfect. The word "electric" may sometimes be mistakenly transformed into words other than electric, and hence these patents are not in our listing. Moreover, a few patents employed electrical technology, but the patent grant documents that described the inventions did not contain the key word. For these reasons, our tentative list may not include all inventions using electrical technology. Thus, we verified the data from LexisNexis with those directly obtained from USPTO when the LexisNexis transcriptions were garbled. Moreover, we cross check the total number of patents listed by our LexisNexis search with samples from Lamoreaux and Sokoloff (1999) and Sutthiphisal (2006). Our list appears to include almost all patents that used the electrical technology.

${ }^{13}$ We also classify these crossover inventions granted to U.S. residents according to the most likely primary users of the invention: households (such as an electric razor) or industrial users (for example, an electric stop motion for warping machines). The shares of patents intended for the two types of users are roughly the same. 
(over 19,000 patents in total) by using the inventor-name search inquiry in LexisNexis. We also establish whether or not these patents have anything to do with the electrical technology. More importantly, we create another list of crossover patents that were filed in both 1890 and 1910 but retrieved by using the inventor name search. We compare such a list with our original list of crossover inventions, and the two lists are almost identical.

We also retrieve biographical information for these patentees from manuscripts of the U.S. decennial population census in 1850-1880 and 1900-1930; city directories; newspaper obituaries; as well as family and local histories. ${ }^{14}$ Among the information collected are: year of birth, birthplace, occupation, place of business, and place of residence at several points during an inventor's life. We are particularly interested in the educational and occupational background of the inventor around the time when he received his first crossover patent.

In addition to the data on crossover inventions, we employ other datasets on core electrical inventions and overall inventive activity. The core electrical invention data come from the cross-section samples collected by Sutthiphisal (2006). They contain similar information on core electrical patents (and their patentees) granted in 1890 and 1910. Data on overall inventive activity are from the cross-section samples constructed by Lamoreaux and Sokoloff (1999). Their data have similar patent information for all industries from a randomly drawn sample of patents granted in 1870-1871, 1890-1891 and 1910-1911.

\section{GEOGRAPHIC ANALYSIS}

\footnotetext{
${ }^{14}$ The majority of 1890 population census manuscripts were destroyed.
} 


\section{A. General Patterns}

To probe whether, and the extent to which, different factors helped facilitate the diffusion of the electrical knowledge and spur crossover inventive activity, we compare the geographic patterns of these factors with that of crossover inventions. Figure 1 shows that in general the location of crossover inventions (as measured by regional shares of crossover patents) was not so closely related to the location of core electrical inventions (measured by regional shares of core electrical patents), regardless whether we examine the geographic patterns in the same year or the pattern of changes over time. The leading centers of crossover inventions remained in the same places (New York and East North Central) in both 1890 and 1910, while the centers of core electrical inventions changed dramatically from 1890 to 1910 . The importance of Massachusetts in core electrical inventions in 1890 was later replaced by Pennsylvania and East North Central by $1910{ }^{15}$ Such findings challenge the relevance of inter-industry spillovers in crossover inventive activity as they were expected to be more prominent at the center of core inventions.

In contrast, the location of crossover inventions better mirrored that of overall inventions (measured by regional shares of inventions in all industries). For example, in 1890, Massachusetts, the second largest center of core electrical inventions, accounted for more than $20 \%$ of such inventions in the country, but it contributed less than $10 \%$ of crossover and overall inventions. Similarly, in 1910, Pennsylvania's share of core electrical inventions was more than $20 \%$, nearly twice of its shares of crossover (11.4\%)

\footnotetext{
${ }^{15}$ The weak geographic association between core electrical and crossover inventions is even more apparent at the county level. The main centers of core electrical invention: Lynn (home of the ThomsonHouston Electric Company) in 1890, and Pittsburg (Westinghouse Electric Company) and Schenectady (General Electric Company) in 1910 all had disproportionately low shares of crossover inventions. In fact, the shares of crossover inventions in these three counties were less than one-fourth of their shares of core electrical inventions.
} 
and overall inventions (9.9\%). Since overall inventive activity likely appeared in the same areas where these general conditions were prevalent, the closer association between the regional shares of crossover inventions and those of overall inventions suggests that conditions conducive to inventive activity in general may be more important.

In addition to conditions conducive to inventive activity, the other two factors, learning-by-using and appropriate human capital, may play a role in diffusing electrical technology and thereby stimulating crossover inventions. There are two measures of electric utilization that can help us assess the impact of learning-by-using spillovers. One is regional shares of electric power usage in manufacturing establishments (horsepower for 1890 and the number of motors in 1910). ${ }^{16}$ The other is regional shares of telegraph operators which perhaps reflect utilization of electrical technology more broadly since electric telegraph may be accessed by all types of firms and also by households. A reasonable measure of the distribution of appropriate human capital is regional shares of individuals who held occupations in science, such as chemists, physicists and engineers.

Table 2 reports these measures for learning-by-using and appropriate human capital together with regional shares of patents and population. However, it is difficult to tell from eyeballing Table 2 how well the geographic patterns of these factors explained the location of crossover inventions, compared to the location of overall inventions. In addition, unlike the comparison between regional shares of different types of inventions, electric utilization in manufacturing establishments, telegraph operators and individuals

\footnotetext{
${ }^{16}$ The number of motors would be a better measure of electricity employment in manufacturing than total horsepower because the mechanisms behind a motor with low horsepower were the same as those with higher horsepower. Furthermore, the ideal measure of electric utilization should include electric power used in households as it may not be necessary to work in a factory in order to be used to the technology or realize its potential applications. Unfortunately, the census of manufactures did not report the number of electric motors used in 1890, nor did the electric utilization by households.
} 
in scientific occupation are distinctly different from patents. It may not be sensible to gauge the relative importance of learning-by-using and human capital using these measures without controlling for regional characteristics such as the size of population.

\section{B. Multivariate Analysis}

We, thus, apply regression analysis to evaluate our hypotheses. The first model we explore examines whether a count of the number of crossover inventions occurring in a region can be explained by how concentrated the factors in question were in the area while controlling for other regional characteristics. Because many areas, such as Arizona and Kentucky, generated zero to few crossover inventions and only a handful, for example, New York and Ohio, accounted for a very large share of crossover inventions in the country, our data are skewed to the right. As a result, we employ a negative binomial specification. ${ }^{17}$ The dependent variable is state $i$ 's number of crossover patents in year $t$, while the scalar product of the vector of regressors and the vector of coefficients can be written as:

$$
\alpha+\beta_{1} \cdot \ln \left(\text { core }_{\text {it }}\right)+\beta_{2} \cdot \ln \left(\text { overall }_{\text {it }}\right)+\gamma_{1} \cdot \ln \left(\text { pop }_{\text {it }}\right)+\gamma_{2} \cdot \ln \left(d_{i t}\right)
$$

pop $_{i t}$ denotes the state's number of population, to control for the possibility that states with larger population may generate more inventions. $d_{i t}$ is the population density to control for amenities that are often lacking or of poorer quality in under-populated areas, such as public libraries. Most importantly, we include core $_{i t}$, state $i$ 's number of core electrical patents in year $t$, so as to gauge the impact of inter-industry spillovers between core electrical and crossover inventors. The other independent variable, overall ${ }_{i t}$, is state i's number of all patents which is a proxy for the impact of conditions that were

\footnotetext{
${ }^{17}$ See, Hausman et al. (1984) and Cameron and Trivedi (1999).
} 
important to inventive activity in general. $\beta_{1}$ and $\beta_{2}$ will, therefore, provide an indication into the relative importance of inter-industry spillovers and conditions conducive to inventive activity in general on crossover invention.

We use states as our unit of observations because the census data were reported at the state level. Also, an estimation at a larger geographic level, instead of at the smaller county level, may be more appropriate in assessing the effects of inter-industry spillovers and learning-by-using, the two factors that we are particularly interested in, that can easily occur across county lines. On a daily basis, one may exchange information on the electrical technology and its potential application with people from the same county as well as those from neighboring counties.

The estimation results are reported in column 1 of Table 3. The positive estimate for $\beta_{1}(0.137)$ suggests that inter-industry spillovers had a positive impact on the number of crossover inventions. However, the effects were much smaller than conditions conducive to inventive activity in general, as the estimated $\beta_{2}(0.992)$ is much larger and more statistically significant. ${ }^{18}$

The regression model specified in columns 2 includes two different measures of learning-by-using in the set of explanatory variables: the natural logarithm of state $i$ 's number of telegraph operators and the natural logarithm of the state's electric utilization in manufacturing establishments. To assess what role human capital played in the diffusion of the electrical technology, we also add the natural log of the state's total number of individuals who held occupation in scientific fields. ${ }^{19}$ The results in column 2 show a large coefficient for overall inventions (0.597) and a much smaller estimate for

\footnotetext{
${ }^{18}$ We obtain similar results at the county level for the model specified in column 1 of Table 3.

${ }^{19}$ See Appendix 3 for a more detailed classification of scientific occupations.
} 
core electrical inventions (0.085), corroborating the previous findings that inter-industry spillovers were not as critical as conditions that promoted inventive activity. Moreover, there is strong evidence that supports the importance of human capital. The coefficient on the natural $\log$ of the number of individuals with scientific occupations (0.674) is not only significantly positive but also the largest in size. In addition, the estimation implies that learning-by-using played a limited role in general, although the impact was slightly more pronounced through manufacturing experience (0.196).

To capture regional specific effects, we add regional dummies in our regression. The regression results are reported in column 3 of Table $3 .^{20}$ On the whole, the patterns are comparable to those found in column 2. Conditions conducive to inventive activity in general remained an important factor in explaining a region's total number of crossover inventions, although the impact was somewhat attenuated. Column 3 also reveals an even larger estimated coefficient for the natural log of the number of people with scientific occupations. Such a finding again confirms the importance of appropriate human capital in the diffusion of the newly developed electrical technology and the generation of crossover inventions. ${ }^{21}$

There is, nonetheless, one concern with the results reported in Table 3, which show that variation in some of the factors, for example, appropriate human capital, had a much larger effect on crossover inventions while variation in others, such as core inventions, had little influence. If there is not much variation in appropriate human capital across regions but instead the regional difference in core inventions is large, it is

\footnotetext{
${ }^{20}$ See Figure 1 note for regional classification.

${ }^{21}$ In an unreported regression specification where manufacturing labor force is added into the set of regressors, the results are consistent with those reported in Table 3.
} 
possible that core inventions may turn out to better explain the variation we observed in crossover inventions than appropriate human capital does.

We, therefore, estimate another regression model to investigate such a possibility, and focus on exploring the relative abundance of a factor in an area as compared to other regions, and how such a deviation from the center of the data affects the ability to generate crossover inventions. The regression specification has the following form.

$$
\begin{array}{r}
\frac{\text { cross }_{i t}-\overline{\text { cross }_{t}}}{S D\left(\text { cross }_{t}\right)}=\beta_{1} \cdot \frac{\text { core }_{i t}-\overline{\text { core }_{t}}}{S D\left(\text { core }_{t}\right)}+\beta_{2} \cdot \frac{\text { overall }_{i t}-\overline{\text { overall }_{t}}}{S D\left(\text { overall }_{t}\right)} \\
+\gamma_{1} \cdot \frac{\text { pop }_{i t}-\overline{\text { pop }_{t}}}{S D\left(\text { pop }_{t}\right)}+\gamma_{2} \cdot \frac{d_{i t}-\overline{d_{t}}}{S D\left(d_{t}\right)}+\varepsilon_{i t}
\end{array}
$$

where $\operatorname{cross}_{i t}$, is state $i$ 's number of crossover patents in year $t, \overline{\text { cross }_{t}}$ denotes the average number of crossover patents across regions in year $t$ and $S D\left(\right.$ cross $\left._{t}\right)$ represents the sample standard deviation of the number of crossover patents in year $t$. Such a transformation is applied to the regressors as well. $\varepsilon_{i t}$ is the disturbance term.

Table 4 reports the estimation results, which are consistent with those obtained from the count-data regression reported in Table 3. Column 1 reveals a strong impact of overall patenting but a relatively small effect of core electrical patenting. A one standarddeviation increase in the number of patents in all kinds of industries was associated with a $80.1 \%$ standard-deviation increase in crossover patents. In contrast, a one standarddeviation increase in the number of core electrical patents was only seen together with a 26.6\% standard-deviation increase in crossover patents. Column 2 adds proxies for learning-by-using and appropriate human capital. The results show that appropriate human capital also boosted crossover inventive activity significantly. Learning-by-using, however, had little, if not negative, impact. In column 3, we include regional dummies in 
our regression to control for state specific effects. The results reported in column 3 are comparable to those in column 2. The importance of conditions that encouraged inventive activity in general persisted. Also, appropriate human capital exhibited a positive effect despite that its significance slightly attenuated after the inclusion of regional dummies.

What shaped the geography of crossover inventions and enhanced the population's ability to understand electrical technology and apply it to other fields? The evidence shows that the contribution of inter-industry knowledge spillovers may have been overstated in the literature. In contrast, conditions conducive to inventive activity in general appeared to be a more significant factor in explaining the number of crossover inventions generated in each region. The multivariate analysis also highlights the importance of appropriate human capital, and reveals the limited role of learning-byusing.

\section{INDIVIDUAL ANALYSIS}

\section{A. Biographical Characteristics of Crossover Inventors}

To gain more insight into how these factors affected the diffusion process of the electrical technology into inventive activity in downstream industries, we turn our attention to individuals who created crossover inventions. We begin with identifying who these crossover inventors were and how their inventive career evolved over time. Such an investigation will provide us some idea of ways that inter-industry spillovers influenced these inventors. If knowledge exchange between individuals in the core electrical industry and those in other industries (inter-industry spillovers) played an important role in facilitating crossover inventions, we would expect a significant number of inventors who started their inventive career in the core electrical field to apply their knowledge to 
generate crossover inventions. Thus, such inventors would account for a great number of crossover inventions. Inventors would also tend to generate and switch inventions back and forth in different fields as they learned about opportunities in industries in which they had no work experience. They may develop items to be used in a range of crossover industries, or even be able to employ their acquired knowledge to generate inventions in the core electrical field.

However, the findings from an investigation into lifetime patenting behaviors of crossover inventors do not support the idea that inter-industry spillovers played a pivotal role for the inventive activity of individuals who made crossover inventions. As Table 5 shows, only 9\% of crossover inventors in 1890 and 11\% in 1910 were those who started out their inventive career in the core electrical inventors. These inventors, though slightly more productive at creating crossover inventions than others, contributed only a small portion of crossover patents (12\% in 1890 and $11 \%$ in 1910). In contrast, the majority of crossover patents were made by individuals who began their career directly with a crossover patent or a patent that did not have any electrical technology embedded. ${ }^{22}$

Table 6 further reveals that inventors who started in a different field seldom switched back and forth the industry to which their later inventions were applied. A median crossover inventor whose first patent was in the core electrical field generated a total of 23 patents over his lifetime but less than 4 were crossover patents. Similarly, those who did not begin their career in the core electrical industry hardly ever applied their acquired electrical knowledge to carry out inventions in the core electrical field.

${ }^{22}$ One may argue that some of the crossover inventions were trivial improvements with little market value. However, the assignment-at-issue rate of crossover invention (35\% in 1890 and $45 \%$ in 1910) is higher than that of overall inventions from the Lamoreaux and Sokoloff (1999) sample (roughly $30 \%$ in both years). In addition, the relative importance of these three different types of inventors still hold even if we only focus on "valuable" crossover patents (that is, patents that were assigned - sold - at issue). 
Less than 7 percent of their lifetime inventions were in the core electrical field. ${ }^{23}$ Even if these crossover inventors did switch, it generally took them quite some time. For example, it took those who started out as core electrical inventors at least five years, on average, to make their first crossover invention after their first ever invention.

These results reinforce our earlier finding from the geographic analysis that interindustry spillovers did not appear to be an important factor in the diffusion of electrical technology to inventive activity in other fields. What did influence individuals to create crossover inventions? To answer this question, we probe the educational and training background of the crossover inventors in comparison with that of other inventors. Such an exploration helps us not only assess the impact of human capital, but also identify what kinds of human capital were more critical than others.

Table 7 reports the educational background of crossover inventors. Crossover inventors were markedly distinguished by their advanced education. A much higher proportion of them (the normalized share was $28 \%$ in 1890 and $50 \%$ in 1910 ) received some college education than did shoe and textile inventors in the same cross-section years (less than 10\%). ${ }^{24}$ In fact, the 1910 figure was similar to that of inventors who focused on electric-related inventions (49\%). Among crossover inventors, those whose

\footnotetext{
${ }^{23}$ It may be too restrictive to only categorize inventors according to their first invention. We also employ a more relaxed classification scheme, that categorizes an inventor by looking at the first two years of his inventive career, starting from the date he applied for his first ever patent. For example, if the inventor generated more core electrical inventions than other types (crossover and "other") within these two years, we classify him as a core inventor. This classification scheme yields almost identical results.

${ }^{24}$ For crossover inventors, we infer whether they attended college from census manuscripts, city directories, and newspaper obituaries as well as family and local histories. See Appendix 3 for more details on education classification. Sutthiphisal (2006) retrieved educational background of shoe and textile inventors primarily from the census manuscripts and city directories. Thus, we have a higher matching rate for the educational background of our crossover inventors. This may be part of the reason why we find that a much larger proportion of crossover inventors went to college than shoe and textile inventors. Nonetheless, based on the occupational description in the census manuscripts and city directories of shoe and textile inventors, we believe that, even after taking into account the matching bias, there remains a significant difference in educational background between crossover and shoe-textile inventors.
} 
first patent was in the core electrical field had the highest percentage (50\% in 1890 and $65 \%$ in 1910) receiving some college education but the difference between such inventors and other crossover inventors eroded over time.

Table 8 summarizes prior training of crossover inventors before the sample year as well as before they applied for their first patents. We classify training according to both education and job experience. ${ }^{25}$ Crossover inventors were distinguished by their advanced skills. In 1890, 28\% of crossover inventors had some training in the electrical field and $40 \%$ were in other technical fields, such as chemistry, physics and dentistry. A total of $68 \%$ crossover inventors had high technical skills. In contrast, less than $40 \%$ did among shoe and about 50\% for textile inventors. The same patterns persisted in 1910 .

Despite having advanced technical skills, many crossover inventors did not seem to rely on direct training in electrical technology. Less than $25 \%$ of the crossover inventors (19\% in 1890 and 24\% in 1910) had received training or had worked in the electrical field before they applied for their first patent. On the other hand, $41 \%$ in both years had been trained or had work experience in other technical fields. The population census manuscripts and city directories show that, before obtaining their first patent, many crossover inventors were employed as engineers, machinists, chemists, and professionals in other sciences. For example, Byron A. Brooks, a typewriter pioneer, invented numerous improvements in typewriting machines. He applied electrical

${ }^{25}$ Working out whether an inventor attended college is extremely difficult, as the large proportions of inventors for whom we can find no information attests. Some likely attended college but did not graduate which makes it even harder to find out about their educational background. It is much more often possible to find out the training of these inventors through their occupational background than an answer to the question "did they attend a college?" For about $80 \%$ of the 1890 inventors and almost $90 \%$ of the 1910 inventors, we can find some information about their previous training. Ideally, we would like to compare the training background of inventors across samples. Unfortunately, the Sutthiphisal (2006) sample does not contain information on when the inventors applied for their first patents. Therefore, we can only gauge the difference in training background of inventors in the sampled years. 
technology to a number of his inventions later in his career. He was a professor of mathematics before receiving his first patent. The fact that the majority of crossover inventors were individuals like Brooks, who went to college and received training or held an occupation in advanced technical fields, such as mathematics, physics, and machinery, but not particularly in the electrical field highlights the contribution indirectly made by learning institutions in the diffusion of electrical technology. These institutions provided technical foundations and principles which were scientifically close or complementary to the electrical field. Such a background made it easier for one to absorb the newly developed electrical technology.

Thus far, the exploration into inventors' biographies has shown the limited role played by inter-industry spillovers and underlined the importance of technical education and training (not necessarily in the field of the electrical technology). The detailed information we have collected about individuals also allows us to further examine whether, and to what extent, technical training and other factors affected the speed at which inventors used electrical technology to create their first crossover invention as well as their productivity at making them.

\section{B. The Speed and Productivity of Inventors at Producing Crossover Inventions}

An inventor who received training in the core electrical field or in some other highly technical field, is likely to create his first crossover invention at a younger age and generate more crossover inventions over his entire life than one who did not have such training. In addition to appropriate education and training, other factors, such as interindustry spillovers, may also help inventors obtain the knowledge of the newly developed technology. To examine these conjectures, we look into how the factors affected the time 
it took for an inventor to make his first crossover invention. The less time it took for an inventor to do so, the faster the electrical technology was assimilated.

A straightforward investigation of the timing of the first crossover invention in one's career can be carried out by estimating the following specification.

$$
\begin{aligned}
&{\text { - } \text { agecross }_{i}=\alpha+\sum_{j}} \delta_{j} \cdot \text { train }_{i j}+\beta_{1} \cdot \ln \left(\text { core }_{i}\right)+\beta_{2} \cdot \ln \left(\text { overall }_{i}\right) \\
&+\gamma_{1} \cdot \ln \left(\text { tel }_{i}\right)+\gamma_{2} \cdot \ln \left(\mathrm{mfg}_{i}\right)+\theta_{i} \cdot \text { college }+Z_{i} \lambda+\varepsilon_{i}
\end{aligned}
$$

agecross $_{i}$ is the age at which inventor $i$ filed his first crossover patent. The younger the inventor at the time of first filing, the shorter the time period it took him to assimilate the newly developed electrical technology. Therefore, transforming agecross $_{i}$ to - agecross $_{i}$ for the dependent variable allows us to interpret the effects of covariates in a usual and more natural fashion: a positive estimated coefficient shortens the time elapsed to the first crossover invention and thereby speeds up the process of diffusion.

$\operatorname{train}_{i j}$ 's are a series of dummies, indicating which type of training $j$, inventor $i$ received prior to applying for his first patent. There are five different types of training. Appendix 3 describes each training category. ${ }^{26}$ The estimated coefficients on these dummies reflect the impact of different types of technical training on the speed at which the electrical technology was employed to generate the first crossover invention. core $_{i}$ is the number of core electrical patents granted to residents in the state where inventor $i$ resided, measured in per million capita around the time when the first crossover patent was filed. A large value of core $_{i}$ represents a high concentration of core electrical ideas, and thereby individuals in other fields would be more likely to benefit from inter-industry

${ }^{26}$ Roughly $80 \%$ of inventors in our sample did not seem to receive any additional different training after they received their first patent but before the sample years. 
spillovers. Similarly, overall ${ }_{i}$ is the number of total patents awarded to residents in the same state in per million capita, capturing the prevalence of conditions conducive to inventive activity. ${ }^{27} t l_{i}$ is the number of telegraph operators in inventor $i$ 's state per thousand capita while $m f g_{i}$ is electrical utilization in manufacturing for the same state per thousand capita, again around the time that the first crossover patent was filed. ${ }^{28}$ Both $t e l_{i}$ and $m f g_{i}$ provide us an indication of the prevalence of electrical utilization where the inventor was located, and hence the likelihood that he became familiar with the electrical technology. college $_{i}$ is a dummy variable indicating whether an inventor had ever attended college. Attending college and other institutions of higher learning may make it easier to learn about the new technology. College study prepared one to think critically, to synthesize theory and application and to develop new ideas or concepts. Several college curricula even included at least some training in basic sciences for all students. ${ }^{29}$

\footnotetext{
${ }^{27}$ There are a few concerns with what core and overall actually reflect for those who started their inventive career in the core electrical field. For such inventors, core may reflect the effects of intraindustry spillovers rather than inter-industry spillovers, and overall may capture the likelihood that they learned about potential application of the electrical technology in other fields (that is, inter-industry spillovers) in addition to the intensity of conditions conducive to inventive activity. However, given that these individuals who started out as core inventors account for roughly $10 \%$ of the inventors and crossover patents in the sample (Tables 5), our analysis thus focuses on those who began their career as crossover and other inventors. Also, we verify whether core and overall do indeed reflects inter-industry spillovers and conditions conducive to inventive activity by running separate regressions on individuals with different prior training background. For example, for those who were not trained in the electrical fields, the coefficient on core reflects inter-industry spillovers and the coefficient on overall represents the effects of conditions conducive to inventive activity. The unreported results are consistent with Tables 9 and 10.

${ }^{28}$ Ideally, we should use data on core, overall, tel and $\mathrm{mfg}$ at just before the inventor applied for his first crossover patent. Unfortunately, we do not have such data. The second best alternative, that we pursue here, is to use the data around the time that the inventor filed for his first crossover patent. That is, if the first crossover patent was filed before 1881, we employ the 1870 figures; the 1890 figures if the file year was between 1881 and 1900; and the 1910 figures if the file year was after 1900. In addition, there are no data available for 1870 electric utilization nor number of telegraph operators, and the number of core electrical patents were very small in 1870 (18 patents). This is not surprising considering that electrical technology emerged commercially in the late 1880s. We therefore set the measures for electric utilization and core inventions equal to zero for all states in 1870 .

${ }^{29}$ Brubacher and Rudy (1958, p. 113) point out that for American higher education in the second half of the 19th century, "even humanistic fields like literature, history, and philosophy felt honor-bound to
} 
Such preparation provided a great advantage for those having received college education to absorb the electrical technology which was not only abstract but also scientific in nature. Finally, $Z_{i}$ is a row vector of other control variables, such as "birth year" to control for different technological opportunities facing inventors who were born in different eras.

A least squares estimation on equation (3) inevitably implies that time duration conditioned on all covariates follows a normal distribution. However, the time (conditioned on the covariates) to the occurrence of the first crossover patent in fact is likely not symmetrical and certainly does not take on a value less than zero. To address this issue, we follow the literature that studies time to event occurrence using the socalled duration model. ${ }^{30}$

The model can be characterized using a hazard function, $h(t \mid X)$, that is defined as the probability (arrival rate) that inventor $i$ creates his first crossover patent at time $t$ (given his characteristics $X$, a row vector), conditional on the fact that he has failed to do so until $t$. We employ the proportional hazard model, which decomposes the hazard function into two components: one describes the impact of waiting time and the other demonstrates the influence of $X$, which is captured through a set of unknown parameters, $\beta$. We thus have the following hazard function

$$
h(t \mid X)=h_{0}(t) \cdot \phi(X, \beta)
$$

prove that they, too, had their "scientific” side and were based on precise data." Also, see Guralnick (1975) for development of American college curriculum in sciences during the Antebellum period.

${ }^{30}$ See, for example, Lancaster (1979), Rose and Joskow (1990), and Karshenas and Stoneman (1993). For literature review on various duration models and areas of application, see Kalbfleisch and Prentice (1980) and Kiefer (1988). 
$h_{0}(t)$, is the base hazard function. We follow the common practice in much of the literature to specify $\phi(X, \beta)=\exp (X \beta)$. In brief, $h_{0}(t)$ represents the arrival rate for an inventor whose $X=0$, while the term $\exp (X \beta)$ allows the arrival rate to vary by inventor $i$ 's characteristics.

Employing agecross as $t$ and the set of explanatory variables in equation (2) to be our $X$, we fit our data to the Weibull proportional hazard model, in which the base hazard function, $h_{0}(t)$, is of the form $p \cdot t^{p-1} \cdot p$ is the Weibull shape parameter, and it is simultaneously estimated together with $\beta$. The estimation results are reported in Table 9. ${ }^{31}$ Column 1 contains all crossover inventors for whom we are able to infer their training information. Column 2 only includes inventors who remained at the same state residence between their first patent and first crossover patent, because it would be difficult to obtain appropriate covariates for an inventor who relocated to a different state. ${ }^{32}$ Columns 3 and 4 further restrict our observations to inventors for whom educational background is known.

All the columns display positive estimated coefficients for all training dummies. Training in electrical technology particularly as electricians or electrical engineers (positions that required the most technical and direct knowledge of electrical technology)

${ }^{31}$ We also employ the semiparametric approach proposed by Cox (1972 and 1975), which makes no assumption about the form of the base hazard function, $h_{0}(t)$. This unreported estimation yields a close match to those found in Table 9. However, the fully parametric Weibull model we have chosen posits a unique advantage over the nonparametric, semiparametric and other parametric analyses. It allows us to interpret regression results in terms of hazard (odds) of creating crossover inventions as well as expected waiting time of their occurrence because the proportional hazard and accelerated failure time models are essentially identical for a Weibull distribution. See, Carroll (2003), for the advantage of the Weibull model.

32 One concern with such exclusion of individuals who relocated is that those who were more geographically mobile may be different from those who were not (for example, more productive - see Sutthiphisal, 2004). Hence, selection bias may arise. However, as Table 9 shows, the patterns in columns 13 are quite similar to each other, suggesting that there is little systematic difference in patenting between crossover inventors who moved and who did not. 
was extremely crucial as the estimate on the electrician dummy (for example, 0.47 in column 1) was the largest with respect to all other explanatory variables. In other words, the odds of creating the very first crossover invention was 1.60 times greater for a crossover inventor with prior training in the electrical field, compared to one with no such training (the hazard ratio is 1.60, whereas the 95\% confidence interval is 1.24-2.07). Interpreted in terms of the impact on expected waiting time of an inventor making his first crossover invention, training in the electrical industry, significantly reduced the wait. Even controlling for college education, the importance of direct training in the electrical field seemed to remain, as shown in column 4 . The added college education indicator also yields a positive and rather sizable estimated coefficient (comparable to that for the electrician dummy), highlighting the role of higher education. Inter-industry spillovers also helped inventors to generate their first crossover invention as columns 1-4 all report a positive estimated coefficient on the natural logarithm of the number of core electrical patents. Nonetheless, the impact appeared to be smaller than the effect of having attended college as indicated in column 4 . These four columns also show a positive and relatively large estimated coefficient for overall patenting in the state of residence, suggesting that that conditions that promoted invention in general significantly facilitated the occurrence of crossover inventions. According to column 4, a $1 \%$ increase in overall patenting was associated with a $49 \%$ increase in the odds of a crossover inventor making his first ever crossover patent (the hazard ratio is 1.49 , whereas the $95 \%$ confidence interval is 1.08 2.00). However, learning-by-using appeared to play a limited role as the estimation yields small (or even negative) coefficients on the number of telegraph operators and electric utilization. Such a finding may indicate that the positive effects from learning-by-using 
were too short-lived for one to capitalize on it in making crossover inventions (see, for example, Irwin and Klenow, 1994).

Furthermore, we divide our sample of inventors into three groups based on their early inventive career, as the effects of these factors may vary across different types of inventors. Column 5 investigates those who started out directly as crossover inventors, while column 6 studies those who began their inventive activity by making inventions in fields that did not involve electrical technology. ${ }^{33}$ For this latter type of inventors, we also examine the time it took them to switch to crossover invention. Naturally, the $t$ in our model becomes the time difference between an inventor's age when he applied for his first crossover patent and the age when he applied for his first ever patent. Estimation results are reported column 7 and they show a similar pattern to column 6 .

The results from columns 5-7 suggest that conditions conducive to inventive activity in general, and more importantly, college education played a pivotal role for those who started out directly as crossover inventors. Such inventors made up the largest group of crossover inventors and created nearly half of the crossover inventions in the sample (as shown in Table 5). In contrast, prior training in the electrical field and interindustry spillovers were of more importance for those whose first ever patent was not a crossover but later switched to create one. Perhaps the finding that these factors had asymmetric effects across different types of inventors is not surprising. Exposure to conditions conducive to inventive activity would be critical for those who had never invented but were embarking on making crossover inventions, while such exposure would not matter as much for those who had already been inventors (in other fields).

\footnotetext{
${ }^{33}$ We do not run a separate regression for those who began their inventive career as core electrical inventors because of the small sample size.
} 
Furthermore, college education probably allowed people who had never invented anything to learn about the new technology and directly carry out crossover inventions. Those who had invented in other fields would be more likely to incorporate the newly arrived electrical technology in their inventions if they had received prior training in the electrical field or interacted with individuals possessing electrical knowledge.

To examine whether appropriate training or education also were more important in leading inventors to create many crossover inventions over their entire career, we estimate a negative binomial regression model. We use the same set of covariates in equation (3) as the explanatory variables, but with the total number of crossover patents received by an inventor over his entire life as the dependent variable.

The regression results are reported in Table 10. The observations are restricted in the same way as in the speed regressions except that now we focus only on inventors who lived in the same state of residence over their entire career. ${ }^{34}$ The findings from the productivity regressions are similar to those from the speed regressions. Receiving the most advanced training in the electrical technology and attending college increased an inventor's productivity considerably as the estimated coefficients on the electrician and college dummies are positive and significantly large. For example, according to column 4, crossover inventors with prior training in the electrical field had 2.43 times the productivity of inventors who did not have such training at making crossover inventions. ${ }^{35}$ College educated inventors were 2.19 times more productive. Conditions conducive to inventive activity in general were also important, particularly for those who

${ }^{34}$ We may have selection bias given our exclusion of inventors who did move. However, as columns 1 and 2 in Table 10 show very similar patterns, such exclusion does not seem to yield different qualitative results.

${ }^{35}$ The formula that we use to compute the rate is $\exp (\beta)$. 
directly started out as crossover inventors (note the positive and sizable estimated coefficient with respect to overall patents in columns 1-5 and the negative coefficient in column 6). ${ }^{36}$ On the other hand, inter-industry knowledge spillovers as well as learningby-using appeared to have limited effects. All columns display a positive but relatively smaller estimated coefficient on the natural logarithm of the number of core electrical patents in the inventor's state of residence. Likewise, the coefficients on the two measures of familiarization with the technology were either small or negative.

\section{CONCLUSION}

This paper has studied the process that governs the diffusion of a GPT into inventive activity across various industries. We examined the introduction of electrical technology during the late 19th century U.S. We focus on four key factors that may help facilitate the process: inter-industry spillovers, learning-by-using, appropriate human capital and conditions conducive to inventive activity in general. To gauge the relative importance of these factors, we explore the geographic distribution of crossover inventions, the speed at which inventors employed the technology to create crossover inventions and their productivity at making them.

Contrary to conventional wisdom, knowledge spillovers (inter-industry spillovers and learning-by-using) did not have a great influence on the diffusion of the newly developed electrical technology. They played a limited role in raising the ability of the population to generate crossover inventions. Nor did spillovers significantly accelerate

${ }^{36}$ For those who started out as other inventors the effects of conditions conducive to inventive activity may be more pronounced in their total number of patents (total productivity) but less visible in the number of crossover patents. As Table 6 shows, the median inventor whose first patent was in the "other" field generated about 10 patents in total, yet only 2 of them were crossover inventions. 
inventors in the creation of their first crossover invention or increase their productivity at making crossover inventions over their career.

On the other hand, conditions that encourage inventive activity in general appeared to have helped in the diffusion of the electrical technology. Such conditions influenced the location of crossover inventions as well as the speed and productivity of individuals in making crossover inventions. Appropriate human capital also played a critical role. Areas abundant with individuals holding occupations in scientific fields seemed to have better ability to generate crossover inventions. Furthermore, direct training in the electrical technology (such as electricians and electrical engineers) and attending institutions of higher learning both had great influence on the speed and productivity of inventors at crossover inventions. These learning institutions may have prepared their students to develop the capacity to understand electrical technology as it developed (for example, from instruction in complementary scientific fields such as physics and mathematics) in addition to directly training individuals in the technology.

These findings suggest that knowledge and expertise in specific applications in the downstream industries may be of more relevance to the implementation of a GPT in existing products or machinery than the knowledge of the GPT itself. As a result, factors that affect inventive activity broadly such as the level of human capital and a favorable environment to any inventive activity may matter more than factors that facilitate the diffusion of the specific knowhow of the GPT, such as inter-industry spillovers and learning-by-using. Although it remains to be seen whether the experience of the introduction of electrical technology can be applied to the diffusion of contemporary GPTs, and more generally, the spread of new ideas across industries, our results imply 
that countries would need to raise the level of human capital as well as create a favorable economic environment for inventors to recoup their costs (and extract returns from their inventions), before much of the gain from the diffusion of these new ideas can be materialized. 


\section{APPENDIX 1. THE EARLY ELECTRICAL INDUSTRIES, 1840-1920}

The modern electrical industries can be traced back to the birth of telegraph in the early 19th century. After the successful demonstrations of the telegraph in the mid-1840s, Samuel Morse together with others quickly built telegraph lines from city to city. Soon these lines spanned the continent. As telegraph signals flew through the (often copper) wires as electric currents, continuous improvement of electric dynamos (generators), batteries, and cables occurred simultaneously with the expansion of the electric telegraph industry.

After telegraphy, the second wave of breakthroughs in the electrical industry was in artificial illumination, beginning with arc lighting apparatus. The scientific principle behind the arc light had been known since the early 1800s. In 1878 Charles Francis Brush, a young engineer in Cleveland, Ohio, introduced the first reliable arc lighting apparatus. Brush also invented a new dynamo that would provide a constant current to his lighting device. Brush's arc light system spread to many other US cities as street illumination. However, arc lighting systems were not safe for interior illumination because they produced light by burning electrodes made of carbon.

Indoor lighting came to life as the incandescent lamp was introduced by Thomas Alva Edison. A former staff member of the Western Union Telegraph Company, in 1879 Edison found a substance which could light up an incandescent lamp for more than 40 hours. For his system of incandescent lighting to be used commercially, Edison developed other electrical devices such as large-scale dynamos which later became central power stations. In the early 1880s, central power stations were established throughout major American cities. As highlighted in Thompson (1921, Electronic Book 
Edition): "The incandescent lamp and the central power station, considered together, may be regarded as one of the most fruitful conceptions in the history of applied electricity. It comprised a complete generating, distribution, and utilizing system, from the dynamo to the very lamp at the fixture, ready for use.”

The emergence of central power stations provided ample opportunities to employ electricity and apply the electrical technology. Electric clocks, burglar alarms and stoves are a few examples of early applications of electricity to consumer goods. As dynamos transform mechanical power into electricity, motors convert electricity back into mechanical power and thus open up numerous applications for electricity in factories. Machinery that had previously relied on steam and other power sources was gradually adapted to take advantage of electricity. Mining equipment, industrial control devices such as machine stop motion (that is, a machine brake) and boiler alarms were among common applications of the electrical technology in industrial uses. For more details on the development of the electrical industries, see Passer (1953), Brittain (1974), Devine (1983), and Hughes (1983).

\section{APPENDIX 2. INVENTION CLASSIFICATION SCHEMES}

The index for invention type is inferred from detailed descriptions of invention including paper drawing, specification, and claims. The scheme that classifies patents into three different fields is as follows. (a) Core electrical patents include technological advances in the core electrical industries, for example, telegraphy, electric switches, and electric cables and wires, as well as general purpose dynamos and motors. The core electrical category also includes inventions in artificial illumination such as arc lamps and incandescent light bulbs. An important application of electrical technology occurred in 
the field of electric railways and street cars. The problems associated with electric railways and street cars as well as the solutions to these problems were similar to those facing the electric power industry. For example, in order to use an electric motor to move a streetcar, a constant supply of electricity had to be presented either by electric batteries or by networks of electric wires. Consequently, those who developed inventions in electric railways and street cars were also very much involved in improving the core electrical technology, particularly in the design of electric batteries and in the distribution of electric power. Given that the growth of the electric railways and street cars was intimately related to the development of the electric power industry, we include inventions in the field of electric railways and street cars in the core electrical class. We also classify electric welding patents in the core electric class. Electric welding utilizes high electrical voltage in order to generate sufficient heat to melt metals or alloys. A large part of inventions in this field thus were centered around electrical resistance substances as well as the apparatus that can create and sustain high voltage. (b) The crossover invention category refers to patents that utilize electricity as a power source or somehow employ electrical technology, but not in the fields that are specify in (a). (c) The "other" category refers to patents that neither utilize electricity nor employ electrical technology.

The dividing line between crossover and core electrical inventions is somewhat arbitrary. For example, patents on railway traction and electric welding could be considered as crossover inventions instead of core electrical inventions. We repeated our empirical analysis using different classification schemes. The qualitative patterns of our results do not change. The inventions that could plausibly be put into either category (a) or (b) account for only a small portion of our crossover sample (about one-fourth). 


\section{APPENDIX 3. INVENTOR EDUCATION AND TRAINING CLASSIFICATION SCHEMES}

Similar to Sutthiphisal (2006), the index for college education is inferred from an inventor's occupation reported in a census or city directory during the ages of 11 to 22 as well as information from other biographical resources such as family and local histories, obituaries and university Internet archives located via www.google.com (for example, Massachusetts Institute of Technology, Cornell University, and the University of Wisconsin, Madison). An inventor is classified as receiving no college education if (a) it is stated explicitly in his biography that he did not go to college; (b) an occupation is found for him before the age of 21 ; or (c) he worked as a laborer when he was 22 . An inventor is identified as having some college education if (d) it is stated explicitly in his biography; (e) he was listed as having been a student or an alumnus according to a university Internet archive; or (f) he reported his education in a census or city directory as a student when he was aged 18-22. Out of 390 crossover inventors for whom we can infer education, 139 meet criteria (d) or (e), 28 meet criteria (f), and 11 meet criteria (a).

The index for training is inferred from information given in biographies in family and local histories, obituaries, the occupations reported in U.S. census manuscripts and city directories, as well as university Internet archives. The general scheme that classifies each inventor's training into 5 different categories is as follows. (a) An inventor was trained as an electrician or electrical engineer if his occupation was reported as such, or he received a degree in electrical engineering. (b) An inventor was trained in other electrically related fields if he worked for an electrical, telephone, or telegraph company, but did not have the job title of electrician or electrical engineer (for example, as a salesperson or a machinist). (c) An inventor was trained in other related scientific fields if 
he received a degree in or worked as a physician, dentist, optometrist, pharmacist, physicist, chemist, metallurgist, mathematician, architect, draftsman, or an engineer of other kinds. (Those who were trained as a physician or a dentist would likely have been required at least to take courses in chemistry.) (d) An inventor was trained in other technical fields if he was trained or worked as a machinist, toolmaker, watchmaker, locksmith, gunsmith, boiler maker, and the like. (v) An inventor was trained in other fields (without any technical skill requirements) if he was trained or worked as a farmer, lawyer, or as an employee in a non-electrically-related firm other than a tool and machinery firm.

\section{REFERENCES}

Adams, James D. and Adam B. Jaffe. "Bounding the Effects of R\&D: An Investigation Using Matched Establishment-Firm Data.” RAND Journal of Economics 27, No. 4 (1996): 700-721.

Atack, Jeremy, Fred Bateman, and Robert Margo, "Steam Power, Establishment Size, and Labor Productivity Growth in Nineteenth Century American Manufacturing." Explorations in Economic History (2008), forthcoming.

Atack, Jeremy, Fred Bateman, and Thomas Weiss. "The Regional Diffusion and Adoption of the Steam Engine in American Manufacturing." Journal of Economic History 40, No. 2 (1980): 281-308.

Arrow, Kenneth J. "The economic implications of learning by doing." Review of Economic Studies 29, No. 3 (1962): 155-173.

Bresnahan, Timothy F., and Manuel. Trajtenberg. "General Purpose Technologies: Engines of Growth?” Journal of Econometrics 65 (1995): 83-108.

Brittain, James E. "The International Diffusion of Electrical Power Technology, 18701920.” Journal of Economic History 34, No. 1 (1974): 108-121.

Brubacher, John S., and Willis Rudy. Higher Education in Transition. New York, NY: Harper \& Brothers Publishers, 1958.

Cameron, A. Colin and Pravin K. Trivedi. "Essentials of Count Data Regression.” In A Companion to Theoretical Econometrics, edited by Badi H. Baltagi, 331-348. Oxford, U.K.: Blackwell Publishers, 2001.

Temin, 19-57. Chicago, IL: University of Chicago Press, 1999.

Carroll, Kevin J. "On the Use and Utility of the Weibull Model in the Analysis of Survival Data." Controlled Clinical Trials 24 (2003): 682-701.

Cox, David R. "Regression Models and Life-Tables." Journal of the Royal Statistical Society. Series B (Methodological) 34, No. 2 (1972): 187-220. 
. “Partial likelihood.” Biometrika 62, No. 2 (1975): 269-276.

Crafts, Nicholas. "Steam as a General Purpose Technology: A Growth Accounting Perspective.” Economic Journal 114 (2004): 338-351.

David, Paul A. "The Dynamo and the Computer: A Historical Perspective on the Modern Productivity Paradox.” American Economic Review, Papers and Proceedings 80, No. 2 (1992): 355-361.

Devine, Warren D, Jr. "From Shafts to Wires: Historical Perspective on Electrification.” Journal of Economic History 43, No. 2 (1983): 347-372.

Goldin, Claudia and Lawrence F. Katz. "The Origins of Technology-Skill Complementarity.” Quarterly Journal of Economics 113, No. 3 (1998): 693-732.

Glaeser, Edward L., Hedi D. Kallal, José A. Scheinkam, and Andrei Shleifer. "Growth in Cities.” Journal of Political Economy 100, No. 6 (1992): 1126-1152.

Griliches, Zvi. "Patent Statistics as Economic Indicators: A Survey." Journal of Economic Literature 28, No. 4 (1990): 1661-1707.

Guralnick, Stanley M. Science and the Ante-bellum American College. Philadelphia, PA: The American Philosophical Society, 1975.

Hausman, Jerry, Bronwyn H.. Hall, and Zvi Griliches. "Econometric Models for Count Data with an Application to the Patents-R\&D Relationship.” Econometrica 52, No. 4 (1984): 909-938.

Hughes, Thomas P. Networks of Power. Baltimore, MD: Johns Hopkins University Press, 1983.

Irwin, Douglas A. and Peter J. Klenow. "Learning-by-Doing Spillovers in the Semiconductor Industry.” Journal of Political Economy 102, No. 6 (1994): 12001227.

Jacob, Jane. The Economy of Cities. New York: Random House, 1969.

Jaffe, Adam B. and Manuel Trajtenberg. "International Knowledge Flows: Evidence from Patent Citations." Economics of Innovation and New Technology 8 (1999): 105-136.

Jovanovic, Boyan, and Peter L. Rousseau. “General Purpose Technologies” In Handbook of Economic Growth, Volume 1B, edited by Philippe Aghion and Steven N. Durlauf, 1181-1224. Amsterdam, the Netherlands: North Holland, 2005.

Kalbfleisch, John D. and Ross L. Prentice. The Statistical Analysis of Failure Time Data. New York, NY: John Wiley and Sons, (1980).

Karshenas, Massoud, and Paul L. Stoneman. "Rank, Stock, Order, and Epidemic Effects in the Diffusion of New Process Technologies: An Empirical Model." RAND Journal of Economics 24, No. 4 (1993): 503-528.

Khan, B. Zorina. The Democratization of Invention: Patents and Copyrights in American Economic Development, 1790-1920. New York, NY: Cambridge University Press, 2005.

Kiefer, Nicholas M. "Economic Duration Data and Hazard Functions.” Journal of Economic Literature 26, No. 2 (1988): 646-679.

Kim, Sukkoo. "Industrialization and Urbanization: Did the Steam Engine Contribute to the Growth of Cities in the United States?” Explorations in Economic History 42, Vol. 4 (2005): 586-598. 
Krueger, Alan B. "How Computers Have Changed the Wage Structure: Evidence from Microdata, 1984-1989.” Quarterly Journal of Economics 108, No. 1 (1993): 3360.

Lancaster, Tony. "Econometric Methods for the Duration of Unemployment." Econometrica 47, No. 4 (1979): 939-56.

Lamoreaux, Naomi R. and Kenneth L. Sokoloff. "Inventors, Firms, and the Market for Technology in the Late Nineteenth and Early Twentieth Centuries.” In Learning by Firms, Organizations, and Countries, edited by Naomi R. Lamoreaux, Daniel M. G. Raff, and Peter Temin, 19-57. Chicago, IL: University of Chicago Press, 1999.

LexisNexis. "U.S. Patents.” www.lexisnexis.com (accessed March 2006-October 2007).

Lipsey, Richard G., Kenneth I. Carlaw and Clifford T. Bekar. Economic Transformations: General Purpose Technologies and Long-Term Economic Growth. Oxford University Press, 2006.

Lo, Shih-tse. "Strenghtening Intellectual Property Rights: Experience from the 1986 Taiwanese Patent Reforms.” Mimeo, Concordia University, 2004.

Lucas, Robert E. Jr. "On the Mechanics of Economic Development." Journal of Monetary Economics 22, No. 1 (1988): 3-42.

Malerba, Franco. "Learning by Firms and Incremental Technical Change.” Economic Journal 102, No. 413 (1992): 845-859.

Moser, Petra, and Tom Nicholas. "Was Electricity a General Purpose Technology? Evidence from Historical Patent Citations.” American Economic Review, Papers and Proceedings 94, No.2 (2004): 388-394.

Multimedia Development Corporation. "MSC Malaysia.” www.msc.com.my (accessed May 2007).

My Family.com Inc. "Family Trees.” www.ancestry.com (accessed April 2006-November 2007).

. “Historical Records.” www.ancestry.com (accessed April 2006-November 2007).

. "Stories and Publications.” www.ancestry.com (accessed April 2006-November 2007).

Passer, Harold C. The Electrical Manufacturers, 1875-1900. Cambridge, MA: Harvard University Press, 1953.

Romer, Paul M. “Increasing returns and long-run growth.” Journal of Political Economy 94, No. 5 (1986): 1002-1037.

Rose, Nancy L., and Paul L. Joskow. "The Diffusion of New Technologies: Evidence from the Electric Utility Industry.” RAND Journal of Economics 21, No. 3 (1990): 354-373.

Rosenberg, Nathan. “Technological Change in the Machine Tool Industry, 1840-1910.” The Journal of Economic History 23, No. 4 (1963): 414-443.

. Inside the Black Box. Cambridge: Cambridge University Press, 1982.

Rosenberg, Nathan, and Manuel Trajtenberg. "General-Purpose Technology at Work: The Corliss Steam Engine in the Late-Ninteenth-Century United States.” The Journal of Economic History 64, No. 1 (2004): 1-39.

Saxenian, AnnaLee. Regional Advantage: Culture and Competition in Silicon Valley and Route 128. Cambridge, MA: Harvard University Press, 1994. 
Schmookler, Jacob. Inventions and Economic Growth. Cambridge, MA: Harvard University Press, 1966.

Sokoloff, Kenneth L. "Inventive Activity in Early Industrial America: Evidence from Patent Records, 1790-1846.” Journal of Economic History 48, No. 4 (1988): 813850.

Sutthiphisal, Dhanoos. "The Geography of Invention in High- and Low-Technology Industries: Evidence from the Second Industrial Revolution.” PhD diss., University of California, Los Angeles, 2004.

. "Learning-by-Producing and the Geographic Links between Invention and Production: Experience from the Second Industrial Revolution." Journal of Economic History 66, No 4 (2006): 992-1025.

The Church of Jesus Christ of Latter-day Saints. "Search for Ancestors." www.familysearch.org (accessed April 2006-November 2007).

Thompson, Holland. The Age of Invention: A Chronicle of Mechanical Conquest. New Haven, CT: Yale University Press, 1921. Electronic Book Edition, www.gutenberg.org/etext/2900 (accessed May 2007).

Thomson, Ross. "Crossover Inventors and Technological Linkages: American Shoemaking and the Broader Economy, 1848-1901.” Technology and Culture 32, No. 4 (1991): 1018-1046.

U.S. Bureau of the Census. Census of Manufactures. Washington, DC: GPO, various years.

. Census of Population. Washington, DC: GPO, various years.

U.S. Patent and Trademark Office. "Full-Page Images.” www.uspto.gov (accessed March 2006-October 2007).

. Technology Assessment and Forecast Report: Patent Counts by Country/State and Year - Utility Patents, January 1, 1963 - December 31, 2001. Washington, DC: GPO, 2001.

U.S. Technical Committee on Industrial Classification. Standard Industrial Classification Manual. Revision of the 1945 ed. of manufacturing industries and the 1949 ed. of nonmanufacturing industries. Washington, DC: Executive Office of the President, Bureau of the Budget, 1957.

Wozniak, Gregory D. "Human Capital, Information, and the Early Adoption of New Technology.” Journal of Human Resources 22, No. 1 (1987): 101-112. 
TABLE 1

DISTRIBUTION OF U.S. ELECTRICAL INVENTIONS

\begin{tabular}{lrrrrrr}
\hline \hline & \multicolumn{2}{c}{ No. of patents } & & \multicolumn{2}{c}{ \% of total patents } \\
\cline { 2 - 3 } \cline { 6 - 7 } Class & 1890 & 1910 & & 1890 & 1910 \\
\hline Other industries that use electrical technology & 457 & 856 & & 1.8 & 2.4 \\
Core electrical & 648 & 615 & & 2.6 & 1.7 \\
Electric lighting & 186 & 260 & & 0.7 & 0.7 \\
Electric transportation & 187 & 142 & & 0.7 & 0.4 \\
Other electrical (such as welding) & 45 & 18 & & 0.2 & 0.1 \\
\hline Total from "electric" search in LexisNexis & 1523 & 1891 & & 6.0 & 5.4 \\
\hline \hline
\end{tabular}

Sources and Notes: LexisNexis (U.S. Patents); USPTO (Full-Page Images); and USPTO (2001). The percent of total patents is calculated from the number of patents with respect to the total number of patents granted by USPTO in the respective years reported in USPTO (2001) - 25,322 for 1890 and 35,168 in 1910. Core electrical category denotes inventions that are advancements in the core electrical technology such as those for electric generation, distribution, transmission, wiring and machinery parts for general use. Electric lighting category includes patents intended for electric lighting use such as light bulbs and lamp fixtures. Electric transportation category contains patents intended for electric railroad and trolley. Other electrical category refers to patents that are not advancement in the core electrical technology (not in the core category) but to some extent of general use and are very closely related to the core electrical industry. Finally, the "other industries that use electrical technology" category denotes patents in industries not related to the electrical industry but exploited the electrical technology, that is, the crossover inventions. See Appendix 2 for more details. 


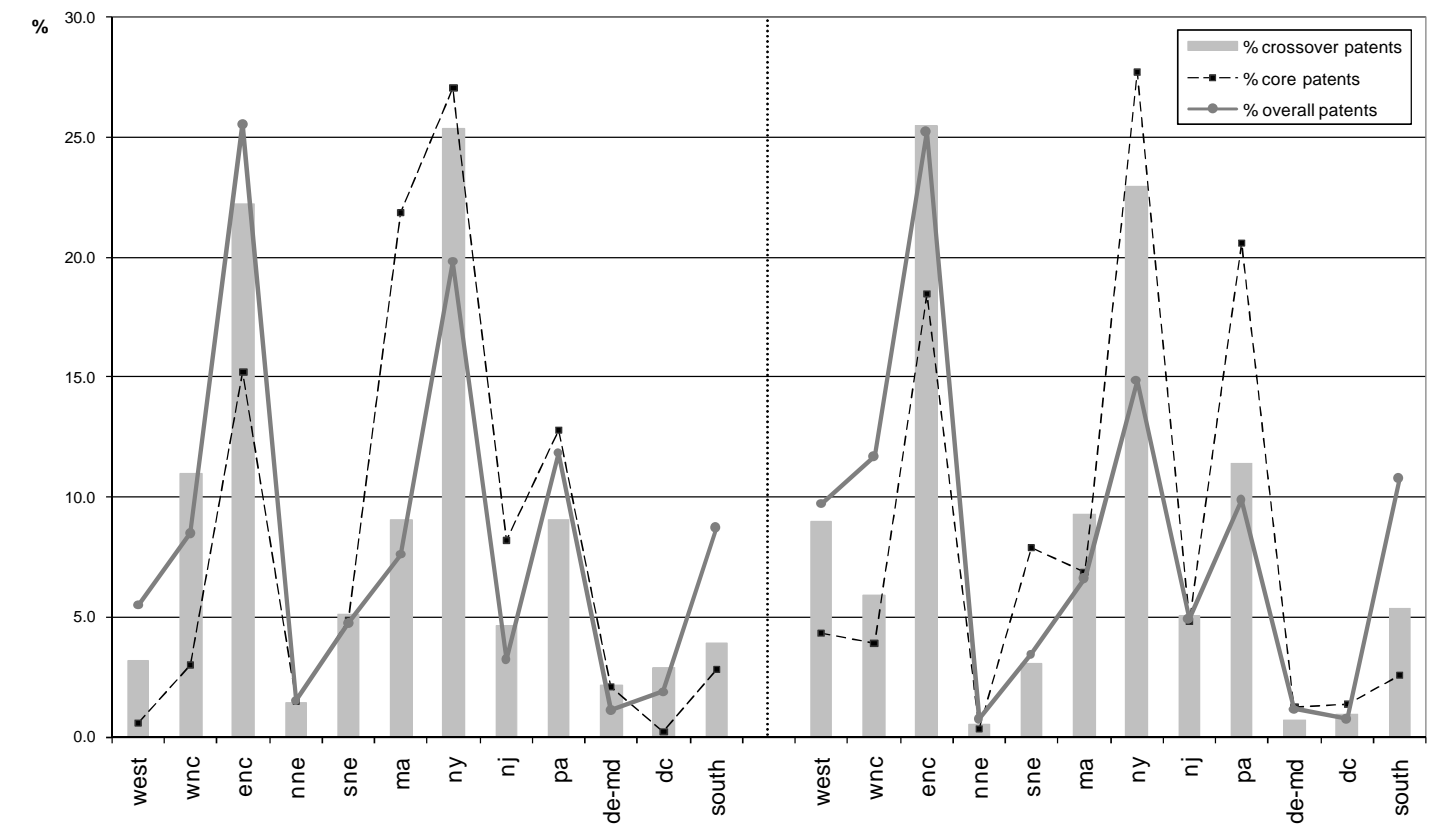

FIGURE 1

Regional Shares of Crossover, Core electrical and Overall Patents, 1890 and 1910

Sources and Notes: LexisNexis (U.S. Patents); USPTO (Full-Page Images); U.S. Census of Manufactures Reports (1890 and 1910); Sutthiphisal (2006); and Lamoreaux and Sokoloff (1999). WNC = West North Central, ENC = East North Central, NNE = Northern New England, SNE = Southern New England. We use a mixture of state and broader regional groupings as the unit of observations. The regional groupings are based on the U.S. Census Bureau. For regions with a high volume of economic (and inventive activity) such as New England and Middle Atlantic, we further divide such regions into smaller units (states). The regions are as follows. (a) West - AZ, CA, CO, ID, MT, NM, NV, OR, UT, WA, and WY. (b) West North Central - IA, KS, MN, MO, ND, NE, and SD. (c) East North Central - IL, IN, MI, OH, and WI. (d) Northern New England - ME, NH, and VT. (e) Southern New England - CT and RI. (f) Massachusetts. (g) New York. (h) New Jersey. (i) Pennsylvania. (j) DE-MD - DE and MD. (k) District of Columbia. (l) South - AL, AR, FL, GA, KY, LA, MS, NC, OK, SC, TN, TX, VA, and WV. (m) Other AK and

HI. 
TABLE 2

SUMMARY OF REGIONAL CHARACTERISTICS

\begin{tabular}{|c|c|c|c|c|c|c|c|}
\hline \multirow[b]{2}{*}{ Region } & \multicolumn{3}{|c|}{ Shares of patenting } & \multicolumn{4}{|c|}{ Other shares } \\
\hline & Crossover & Core & Overall & $\begin{array}{r}\text { Utilization } \\
\text { in manu- } \\
\text { facturing } \\
\end{array}$ & $\begin{array}{r}\text { Telegraph } \\
\text { operators } \\
\end{array}$ & $\begin{array}{l}\text { Individuals } \\
\text { in science } \\
\text { occupation }\end{array}$ & Population \\
\hline \multicolumn{8}{|c|}{ Panel A: 1890} \\
\hline West & 3.2 & 0.6 & 5.5 & 4.3 & 6.8 & 8.7 & 4.8 \\
\hline West North Central & 11.0 & 3.0 & 8.5 & 8.1 & 16.0 & 13.2 & 14.2 \\
\hline East North Central & 22.2 & 15.2 & 25.6 & 24.7 & 26.5 & 21.1 & 21.5 \\
\hline Northern New England & 1.5 & 1.5 & 1.5 & 1.7 & 1.5 & 2.2 & 2.2 \\
\hline Southern New England & 5.1 & 4.8 & 4.7 & 3.2 & 1.5 & 2.0 & 1.7 \\
\hline MA & 9.0 & 21.9 & 7.6 & 14.9 & 2.9 & 5.0 & 3.6 \\
\hline NY & 25.4 & 27.1 & 19.8 & 15.7 & 13.6 & 12.5 & 9.6 \\
\hline NJ & 4.6 & 8.2 & 3.2 & 3.1 & 3.5 & 2.8 & 2.3 \\
\hline PA & 9.0 & 12.8 & 11.8 & 13.9 & 11.6 & 9.0 & 8.4 \\
\hline DE-MD & 2.2 & 2.0 & 1.1 & 2.0 & 1.9 & 1.9 & 1.9 \\
\hline DC & 2.9 & 0.2 & 1.9 & 0.4 & 0.5 & 0.8 & 0.4 \\
\hline South & 3.9 & 2.8 & 8.7 & 7.9 & 13.8 & 20.9 & 29.4 \\
\hline \multicolumn{8}{|c|}{ Panel B: 1910} \\
\hline West & 9.0 & 4.3 & 9.7 & 6.3 & 10.0 & 13.5 & 7.4 \\
\hline West North Central & 5.9 & 3.9 & 11.7 & 7.4 & 14.7 & 10.1 & 12.7 \\
\hline East North Central & 25.5 & 18.5 & 25.2 & 28.2 & 25.2 & 22.1 & 19.8 \\
\hline Northern New England & 0.6 & 0.3 & 0.7 & 1.4 & 1.2 & 1.5 & 1.7 \\
\hline Southern New England & 3.1 & 7.9 & 3.4 & 3.2 & 1.1 & 2.0 & 1.8 \\
\hline MA & 9.3 & 6.9 & 6.6 & 7.5 & 2.3 & 4.9 & 3.7 \\
\hline NY & 23.0 & 27.8 & 14.9 & 17.2 & 10.2 & 13.8 & 9.9 \\
\hline NJ & 5.1 & 4.8 & 4.9 & 4.4 & 2.8 & 3.8 & 2.8 \\
\hline PA & 11.4 & 20.6 & 9.9 & 15.2 & 10.4 & 10.2 & 8.3 \\
\hline DE-MD & 0.7 & 1.2 & 1.1 & 1.7 & 1.9 & 1.7 & 1.6 \\
\hline DC & 1.0 & 1.3 & 0.7 & 0.2 & 0.5 & 0.7 & 0.4 \\
\hline South & 5.4 & 2.5 & 10.8 & 7.2 & 19.6 & 15.7 & 30.0 \\
\hline
\end{tabular}

Sources and Notes: Shares of electric utilization in manufacturing are calculated from the number of horsepower used in manufacturing establishments for 1890; and from the number of electric motors used in manufacturing establishments for 1910. Shares of other electric utilization are computed from the number of telegraph operators. The shares of scientific occupation are calculated from the number of architects, chemists, dentists, engineers, physicians and professors for 1890; and from electricians and electrical engineers, mechanical engineers, stationary engineers, civil engineers, mining engineers, architects, chemists, assayers and metallurgists, college presidents and professors, dentists and physicians for 1910. See Table 1 for sources and geographic classification and Appendix 2 for invention classification. 


\section{TABLE 3}

Negative Binomial Regressions of Number of Crossover Patents

\begin{tabular}{|c|c|c|c|}
\hline Number of crossover patents & $(1)$ & $(2)$ & (3) \\
\hline Constant & $\begin{array}{l}0.027 \\
(0.02)\end{array}$ & $\begin{array}{l}0.486 \\
(0.31)\end{array}$ & $\begin{array}{l}-1.581 \\
(0.46)\end{array}$ \\
\hline ln (number of core patents) & $\begin{array}{c}0.137 \\
(2.53)^{*}\end{array}$ & $\begin{array}{l}0.085 \\
(1.64)\end{array}$ & $\begin{array}{l}0.082 \\
(1.54)\end{array}$ \\
\hline ln (number of overall patents) & $\begin{array}{c}0.992 \\
(8.49)^{* *}\end{array}$ & $\begin{array}{c}0.597 \\
(4.17)^{* *}\end{array}$ & $\begin{array}{c}0.472 \\
(2.93)^{* *}\end{array}$ \\
\hline $\ln$ (noumber of population) & $\begin{array}{l}-0.091 \\
(0.77)\end{array}$ & $\begin{array}{c}-0.531 \\
(2.97)^{* *}\end{array}$ & $\begin{array}{l}-0.174 \\
(0.39)\end{array}$ \\
\hline $\ln$ (population density) & $\begin{array}{l}0.066 \\
(1.32)\end{array}$ & $\begin{array}{l}0.092 \\
(1.92)\end{array}$ & $\begin{array}{l}-0.172 \\
(1.20)\end{array}$ \\
\hline 1910 dummy & $\begin{array}{l}0.019 \\
(0.16)\end{array}$ & $\begin{array}{c}-1.163 \\
(3.41)^{* *}\end{array}$ & $\begin{array}{c}-1.407 \\
(3.17)^{* *}\end{array}$ \\
\hline ln (number of telegraph operators) & & $\begin{array}{l}0.018 \\
(0.10)\end{array}$ & $\begin{array}{l}-0.144 \\
(0.57)\end{array}$ \\
\hline ln (electric utilization in manufacturing) & & $\begin{array}{l}0.196 \\
(1.80)\end{array}$ & $\begin{array}{l}0.219 \\
(1.59)\end{array}$ \\
\hline In (number of individuals in scientific occupation) & & $\begin{array}{c}0.674 \\
(2.92)^{* *}\end{array}$ & $\begin{array}{c}0.817 \\
(2.25)^{*}\end{array}$ \\
\hline Regional dummies & & & yes \\
\hline Observations & 98 & 98 & 98 \\
\hline
\end{tabular}

Absolute value of $\mathrm{z}$ statistics in parentheses

* significant at 5\%; ${ }^{* *}$ significant at $1 \%$

Sources and Notes: The intercepts for columns (1)-(3) are 1890. Also, see Table 2. 
TABLE 4

STANDARD DEVIATION REgRESSIONS OF NUMBER OF CROSSOVER PATENTS

\begin{tabular}{lccc}
\hline \hline Number of crossover patents & $(1)$ & $(2)$ & $(3)$ \\
\hline & & & \\
Constant & & & -4.281 \\
& & & $(0.96)$ \\
Number of core patents & 0.266 & 0.325 & 0.260 \\
& $(5.03)^{* *}$ & $(5.40)^{* *}$ & $(2.92)^{* *}$ \\
Number of overall patents & 0.801 & 0.843 & 0.689 \\
& $(10.62)^{* *}$ & $(8.31)^{* *}$ & $(5.83)^{* *}$ \\
Number of populations & -0.084 & -0.078 & -0.029 \\
& $(1.55)$ & $(0.99)$ & $(0.23)$ \\
Population density & 0.022 & 0.018 & 0.655 \\
& $(0.89)$ & $(0.83)$ & $(1.01)$ \\
Number of telegraph operators & & -0.198 & -0.054 \\
& & $(2.26)^{*}$ & $(0.40)$ \\
Electric utilization in manufacturing & & -0.282 & -0.164 \\
& & $(3.63)^{* *}$ & $(1.59)$ \\
Number of individuals in scientific occupation & & 0.362 & 0.211 \\
& & $(2.91)^{* *}$ & $(1.53)$ \\
Regional dummies & & & yes \\
Observations & 98 & 98 & 98 \\
R-squared & 0.95 & 0.96 & 0.97 \\
\hline \hline
\end{tabular}

Absolute value of $\mathrm{t}$ statistics in parentheses

* significant at $5 \%$; ** significant at $1 \%$

Sources and Notes: See Table 2. 
TABLE 5

CROSSOVER INVENTORS AND INVENTIONS BY TYPES OF INVENTORS

\begin{tabular}{|c|c|c|c|c|}
\hline \multirow[b]{2}{*}{ Types of inventors } & \multicolumn{2}{|c|}{ Inventors } & \multicolumn{2}{|c|}{ Patents awarded to } \\
\hline & Number & Share & Number & Share \\
\hline
\end{tabular}

Panel A: Crossover patents granted in 1890

\begin{tabular}{lrrrr} 
All crossover inventors & 324 & 100 & 410 & 100 \\
First patent was core & 30 & 9 & 49 & 12 \\
First patent was other & 127 & 39 & 157 & 38 \\
First patent was crossover & 153 & 47 & 188 & 46 \\
First patent was unknown & 14 & 4 & 16 & 4 \\
\multicolumn{5}{c}{ Panel B: Crossover patents granted in 1910} \\
All crossover inventors & 610 & 100 & 710 & 100 \\
First patent was core & 69 & 11 & 81 & 11 \\
First patent was other & 234 & 38 & 271 & 38 \\
First patent was crossover & 294 & 48 & 345 & 49 \\
First patent was unknown & 13 & 2 & 13 & 2 \\
\hline \hline
\end{tabular}

Sources and Notes: LexisNexis (U.S. Patents); USPTO (Full-Page Images); and Sutthiphisal (2006). The first patent is classified as unknown for those inventors whose lifetime patenting information is missing. See Appendix 2 for invention classification.

TABLE 6

LIFETIME PATENTING BEHAVIORS OF CROSSOVER INVENTORS

\begin{tabular}{|c|c|c|c|c|c|c|c|c|}
\hline \multirow[b]{2}{*}{ Types of inventors } & \multicolumn{3}{|c|}{ Career patents (median) } & \multicolumn{2}{|c|}{$\begin{array}{c}\text { Share of career } \\
\text { patents (average) }\end{array}$} & \multirow{2}{*}{$\begin{array}{c}\text { Career } \\
\text { length } \\
\text { (avg. } \\
\text { years) }\end{array}$} & \multicolumn{2}{|c|}{$\begin{array}{l}\text { Age (average) when } \\
\text { applied for }\end{array}$} \\
\hline & Total & $\begin{array}{r}\text { Cross- } \\
\text { over }\end{array}$ & Core & $\begin{array}{r}\text { Cross- } \\
\text { over }\end{array}$ & Core & & $\begin{array}{r}\text { First } \\
\text { patent }\end{array}$ & $\begin{array}{r}\text { First } \\
\text { crossover } \\
\text { patent }\end{array}$ \\
\hline \multicolumn{9}{|c|}{ Panel A: Crossover patents granted in 1890} \\
\hline All crossover inventors & 6 & 2 & 0 & 50 & 11 & 19 & 33 & 37 \\
\hline First patent was core & 23 & 3.5 & 9 & 28 & 56 & 26 & 29 & 34 \\
\hline First patent was other & 10 & 2 & 0 & 29 & 7 & 26 & 32 & 41 \\
\hline First patent was crossover & 2 & 1 & 0 & 72 & 6 & 12 & 34 & 34 \\
\hline \multicolumn{9}{|c|}{ Panel B: Crossover patents granted in 1910} \\
\hline All crossover inventors & 7 & 2 & 0 & 55 & 9 & 19 & 33 & 38 \\
\hline First patent was core & 26 & 5 & 6 & 31 & 44 & 28 & 29 & 36 \\
\hline First patent was other & 11 & 2 & 0 & 33 & 5 & 26 & 32 & 42 \\
\hline First patent was crossover & 2 & 2 & 0 & 78 & 4 & 12 & 35 & 35 \\
\hline
\end{tabular}

Sources and Notes: LexisNexis (U.S. Patents); USPTO (Full-Page Images); U.S. Decennial Census of Population Manuscripts (1850-1880 and 1900-1930). We cannot retrieve information on birth year for approximately one-tenth of the inventors in the sample. 
TABLE 7

EDUCATIONAL BACKGROUND OF CROSSOVER AND OTHER INVENTORS

\begin{tabular}{lrrrr}
\hline \hline & & \multicolumn{2}{c}{ Attended college } & Missing \\
\cline { 3 - 3 } Types of inventors & No. of & Unnormal- & Normal- & information \\
inventors & ized share & ized share & (share) \\
\hline
\end{tabular}

Panel A: Crossover patents granted in 1890

$\begin{array}{lrrrr}\text { All crossover inventors } & 324 & 13 & 28 & 54 \\ \text { First patent was core } & 30 & 27 & 50 & 47 \\ \text { First patent was other } & 127 & 13 & 25 & 50 \\ \text { First patent was crossover } & 153 & 12 & 27 & 56\end{array}$

First patent was unknown $\quad 14$

Panel B: Crossover patents granted in 1910

All crossover inventors

First patent was core

First patent was other

First patent was crossover

First patent was unknown
610

69

234

294

13
54

47

50

\section{6}

\section{Panel C: Other patents granted in 1890}

$\begin{array}{lrrrr}\text { Shoes (Sutthiphisal) } & 228 & 1 & 4 & 75 \\ \text { Textiles (Sutthiphisal) } & 339 & 1 & 6 & 81 \\ \text { Electric (Sutthiphisal) } & 312 & 13 & 51 & 75\end{array}$

Panel D: Other patents granted in 1910

\begin{tabular}{lllrr} 
Shoes (Sutthiphisal) & 278 & 0 & 2 & 80 \\
Textiles (Sutthiphisal) & 329 & 1 & 8 & 85 \\
Electric (Sutthiphisal) & 468 & 7 & 49 & 85 \\
\hline \hline
\end{tabular}

Sources and Notes: LexisNexis (U.S. Patents); USPTO (Full-Page Images); U.S. Decennial Census of Population Manuscripts (1850-1880 and 1900-1930); Ancestry.com (U.S. City Directories, and Family and Local Histories); and Sutthiphisal (2006). The normalized shares are calculated from the shares of inventors with known information and they add up to one. See Appendix 2 for invention classification and Appendix 3 for educational background classification. 
TABLE 8

PRIOR TRAINING OF CROSSOVER AND OTHER INVENTORS

\begin{tabular}{|c|c|c|c|c|c|c|c|c|}
\hline \multirow[b]{4}{*}{ Types of inventors } & \multicolumn{3}{|c|}{$\begin{array}{c}\text { Prior training before sample } \\
\text { year } \\
\end{array}$} & \multicolumn{5}{|c|}{ Prior training before applying for first patent } \\
\hline & \multirow{2}{*}{\multicolumn{2}{|c|}{$\begin{array}{r}\text { Normalized share } \\
\begin{array}{r}\text { Other } \\
\text { technical }\end{array}\end{array}$}} & \multirow{3}{*}{$\begin{array}{r}\text { Missing } \\
\text { inform- } \\
\text { ation } \\
\text { (share) } \\
\end{array}$} & \multicolumn{2}{|c|}{$\begin{array}{c}\text { Unnormalized } \\
\text { share }\end{array}$} & \multicolumn{2}{|c|}{ Normalized share } & \multirow{3}{*}{$\begin{array}{r}\text { Missing } \\
\text { inform- } \\
\text { ation } \\
\text { (share) }\end{array}$} \\
\hline & & & & & $\begin{array}{l}\text { Other } \\
\text { hnical }\end{array}$ & & $\begin{array}{r}\text { Other } \\
\text { technical }\end{array}$ & \\
\hline & Electric & skills & & Electric & skills & Electric & skills & \\
\hline \multicolumn{9}{|c|}{ Panel A: Crossover patents granted in 1890} \\
\hline All crossover inventors & 28 & 40 & 20 & 13 & 29 & 19 & 41 & 30 \\
\hline First patent was core & 81 & 8 & 13 & 37 & 10 & 55 & 15 & 33 \\
\hline First patent was other & 14 & 59 & 16 & 6 & 40 & 9 & 54 & 26 \\
\hline First patent was crossover & 29 & 30 & 20 & 16 & 25 & 21 & 35 & 26 \\
\hline \multicolumn{9}{|c|}{ Panel B: Crossover patents granted in 1910} \\
\hline All crossover inventors & 36 & 39 & 12 & 17 & 28 & 24 & 41 & 30 \\
\hline First patent was core & 82 & 17 & 6 & 45 & 14 & 66 & 21 & 32 \\
\hline First patent was other & 21 & 54 & 11 & 9 & 38 & 12 & 54 & 28 \\
\hline First patent was crossover & 36 & 33 & 11 & 17 & 25 & 24 & 34 & 28 \\
\hline \multicolumn{9}{|c|}{ Panel C: Other patents granted in 1890} \\
\hline Shoes (Sutthiphisal) & 0 & 39 & 46 & & & & & \\
\hline Textiles (Sutthiphisal) & 0 & 52 & 50 & & & & & \\
\hline Electric (Sutthiphisal) & 53 & 14 & 47 & & & & & \\
\hline \multicolumn{9}{|c|}{ Panel D: Other patents granted in 1910} \\
\hline Shoes (Sutthiphisal) & 1 & 33 & 41 & & & & & \\
\hline Textiles (Sutthiphisal) & 2 & 48 & 51 & & & & & \\
\hline Electric (Sutthiphisal) & 70 & 19 & 36 & & & & & \\
\hline
\end{tabular}

Sources and Notes: See Table 7. The normalized shares are calculated from the shares of inventors with known information, and they add up to one. The index for prior training before the first patent is inferred from the inventor's previous education or occupation till the year that he filed his first patent (not necessarily being a crossover invention), whereas that before sample years is from the inventor's previous education or occupation up to the sample year. The inventor is classified as having received electrical training if his education or occupation is in categories (a) and (b) of the general training scheme in Appendix 3. On the other hand, the inventor is classified as having received other technical training if his education or occupation is in categories (c) and (d) of the general training scheme in Appendix 3. 
TABLE 9

REgRessions OF SPEED AT WHICH AN INVENTOR CREATED His FIRST CROSSOVER INVENTION

\begin{tabular}{|c|c|c|c|c|c|c|c|}
\hline & (1) & (2) & (3) & (4) & (5) & (6) & \multirow{4}{*}{$\begin{array}{c}\mathrm{Y}=\text { time took } \\
\text { to switch to } \\
\text { crossover and } \\
\text { first patent was } \\
\text { other }\end{array}$} \\
\hline & & $\mathrm{Y}=\mathrm{age}$ & e when applied fo & or first crossove & r patent & & \\
\hline & \multirow[b]{2}{*}{ All } & \multirow{2}{*}{$\begin{array}{l}\text { Not move } \\
\text { between first } \\
\text { patent and first } \\
\text { crossover } \\
\text { patent }\end{array}$} & \multirow{2}{*}{$\begin{array}{c}\text { Not move } \\
\text { between first } \\
\text { patent and first } \\
\text { crossover } \\
\text { patent and } \\
\text { with college }\end{array}$} & \multicolumn{3}{|c|}{$\begin{array}{c}\text { Not move between first patent and first } \\
\text { crossover patent and with college information }\end{array}$} & \\
\hline & & & & $\begin{array}{c}\text { All typesof } \\
\text { first patent } \\
\text { applied }\end{array}$ & $\begin{array}{c}\text { First patent } \\
\text { was crossover }\end{array}$ & $\begin{array}{c}\text { First patent } \\
\text { was other }\end{array}$ & \\
\hline Constant & $\begin{array}{l}-683.484 \\
(21.85)^{* * *}\end{array}$ & $\begin{array}{l}-694.452 \\
(18.71)^{* *}\end{array}$ & $\begin{array}{l}-608.862 \\
(15.59) * *\end{array}$ & $\begin{array}{l}-609.106 \\
(17.08) * *\end{array}$ & $\begin{array}{l}-769.245 \\
(11.88) * *\end{array}$ & $\begin{array}{l}-672.214 \\
(11.75)^{* * *}\end{array}$ & $\begin{array}{l}-103.675 \\
(6.27) * *\end{array}$ \\
\hline Early training was electrician & $\begin{array}{c}0.470 \\
(3.51)^{* *}\end{array}$ & $\begin{array}{c}0.422 \\
(3.11)^{* *}\end{array}$ & $\begin{array}{c}0.596 \\
(3.59)^{* *}\end{array}$ & $\begin{array}{c}0.468 \\
(2.89)^{* *}\end{array}$ & $\begin{array}{l}0.220 \\
(0.92)\end{array}$ & $\begin{array}{l}0.752 \\
(1.22)\end{array}$ & $\begin{array}{l}0.499 \\
(1.03)\end{array}$ \\
\hline Early training was other electrical & $\begin{array}{l}0.270 \\
(1.79)\end{array}$ & $\begin{array}{l}0.248 \\
(1.51)\end{array}$ & $\begin{array}{l}0.263 \\
(1.13)\end{array}$ & $\begin{array}{l}0.205 \\
(0.94)\end{array}$ & $\begin{array}{l}0.020 \\
(0.08)\end{array}$ & $\begin{array}{l}0.601 \\
(0.96)\end{array}$ & $\begin{array}{l}0.222 \\
(0.86)\end{array}$ \\
\hline Early training was in related science & $\begin{array}{l}0.149 \\
(1.38)\end{array}$ & $\begin{array}{l}0.113 \\
(1.14)\end{array}$ & $\begin{array}{l}0.073 \\
(0.51)\end{array}$ & $\begin{array}{c}-0.162 \\
(1.27)\end{array}$ & $\begin{array}{l}0.078 \\
(0.38)\end{array}$ & $\begin{array}{c}-0.101 \\
(0.61)\end{array}$ & $\begin{array}{l}0.074 \\
(0.33)\end{array}$ \\
\hline Early training was other technical & $\begin{array}{l}0.150 \\
(1.53)\end{array}$ & $\begin{array}{l}0.095 \\
(0.95)\end{array}$ & $\begin{array}{l}0.117 \\
(0.74)\end{array}$ & $\begin{array}{l}0.170 \\
(1.13)\end{array}$ & $\begin{array}{l}0.299 \\
(1.37)\end{array}$ & $\begin{array}{l}0.178 \\
(1.19)\end{array}$ & $\begin{array}{c}-0.349 \\
(1.52)\end{array}$ \\
\hline ln (no. of core electrical patents per million capita) & $\begin{array}{c}0.262 \\
(4.32)^{* *}\end{array}$ & $\begin{array}{c}0.238 \\
(3.61)^{* *}\end{array}$ & $\begin{array}{l}0.128 \\
(1.27)\end{array}$ & $\begin{array}{l}0.112 \\
(1.14)\end{array}$ & $\begin{array}{l}0.036 \\
(0.72)\end{array}$ & $\begin{array}{l}0.151 \\
(1.42)\end{array}$ & $\begin{array}{l}0.077 \\
(0.77)\end{array}$ \\
\hline ln (no. of overall patents per million capita) & $\begin{array}{c}0.363 \\
(4.32)^{* *}\end{array}$ & $\begin{array}{c}0.306 \\
(2.77)^{* *}\end{array}$ & $\begin{array}{l}0.382 \\
(1.83)\end{array}$ & $\begin{array}{l}0.398 \\
(1.95)\end{array}$ & $\begin{array}{c}1.415 \\
(4.48)^{* *}\end{array}$ & $\begin{array}{c}-0.132 \\
(1.07)\end{array}$ & $\begin{array}{c}-0.196 \\
(0.76)\end{array}$ \\
\hline In (no. of telegraph operators per thousand capita) & $\begin{array}{l}-0.092 \\
(0.95)\end{array}$ & $\begin{array}{c}-0.139 \\
(1.25)\end{array}$ & $\begin{array}{c}-0.009 \\
(0.06)\end{array}$ & $\begin{array}{l}0.004 \\
(0.03)\end{array}$ & $\begin{array}{l}-0.380 \\
(1.33)\end{array}$ & $\begin{array}{c}-0.109 \\
(0.73)\end{array}$ & $\begin{array}{l}0.025 \\
(0.16)\end{array}$ \\
\hline In (electric utilization per thousand capita) & $\begin{array}{l}-0.988 \\
(8.95)^{* *}\end{array}$ & $\begin{array}{c}-0.913 \\
(6.11)^{* *}\end{array}$ & $\begin{array}{c}-0.813 \\
(6.70)^{* *}\end{array}$ & $\begin{array}{c}-0.801 \\
(6.50)^{* *}\end{array}$ & $\begin{array}{c}-1.105 \\
(5.73)^{* *}\end{array}$ & $\begin{array}{c}-0.813 \\
(8.39)^{* *}\end{array}$ & $\begin{array}{c}-0.242 \\
(3.34)^{* *}\end{array}$ \\
\hline Birth year & $\begin{array}{c}0.340 \\
(21.63)^{* *}\end{array}$ & $\begin{array}{c}0.346 \\
(18.49)^{* *}\end{array}$ & $\begin{array}{c}0.303 \\
(15.38)^{* *}\end{array}$ & $\begin{array}{c}0.303 \\
(16.87)^{* *}\end{array}$ & $\begin{array}{c}0.385 \\
(11.83)^{* *}\end{array}$ & $\begin{array}{c}0.332 \\
(11.72)^{* *}\end{array}$ & $\begin{array}{c}0.055 \\
(6.24)^{* *}\end{array}$ \\
\hline 1910 year dummy & $\begin{array}{c}-3.529 \\
(6.79)^{* *}\end{array}$ & $\begin{array}{c}-3.878 \\
(5.41)^{* *}\end{array}$ & $\begin{array}{l}-3.245 \\
(5.17)^{* *}\end{array}$ & $\begin{array}{c}-3.292 \\
(5.36)^{* *}\end{array}$ & $\begin{array}{l}-4.010 \\
(3.65)^{* *}\end{array}$ & $\begin{array}{l}-3.640 \\
(6.54)^{* *}\end{array}$ & $\begin{array}{l}-0.411 \\
(1.76)\end{array}$ \\
\hline Went to college & & & & $\begin{array}{c}0.385 \\
(4.73)^{* *}\end{array}$ & $\begin{array}{c}0.343 \\
(2.49)^{*}\end{array}$ & $\begin{array}{l}0.130 \\
(0.64)\end{array}$ & $\begin{array}{l}0.083 \\
(0.46)\end{array}$ \\
\hline Observations & 646 & 544 & 287 & 287 & 153 & 105 & 102 \\
\hline $\begin{array}{l}\text { Absolute value of } \mathrm{z} \text { statistics in parentheses } \\
* \text { significant at } 5 \% ;{ }^{*} \text { significant at } 1 \%\end{array}$ & & & & & & & \\
\hline $\begin{array}{l}\text { Sources and Notes: Le } \\
\text { Population (1890 and 1910); U. } \\
\text { Lamoreaux and Sokoloff (1999); } \\
\text { 1930); Ancestry.com (U.S. City } \\
\text { Standard errors are clustered by s } \\
\text { training till the year that he filed } \\
\text { Appendix } 3 \text { for more details on tr }\end{array}$ & $\begin{array}{l}\text { sNexis } \\
\text { Census } \\
\text { S. Dece } \\
\text { Directori } \\
\text { es. The } \\
\text { his ver } \\
\text { ing and }\end{array}$ & $\begin{array}{l}\text { U.S. Paten } \\
\text { of Manuf } \\
\text { anial Censt } \\
\text { es, Newsp } \\
\text { ndex for e } \\
\text { first pate } \\
\text { college cla }\end{array}$ & $\begin{array}{l}\text { nts); USPT } \\
\text { factures (18 } \\
\text { us of Popu } \\
\text { aper Obitu } \\
\text { arly trainin } \\
\text { nt (not nec } \\
\text { assification. }\end{array}$ & $\begin{array}{l}\text { ГO (Full- } \\
890 \text { and } \\
\text { lation Ma } \\
\text { uaries anc } \\
\text { g is infer } \\
\text { essarily b }\end{array}$ & $\begin{array}{l}\text { Page Ima } \\
\text { 1910); Sut } \\
\text { nuscripts ( } \\
\text { Family } \\
\text { ed from th } \\
\text { eing a cros }\end{array}$ & $\begin{array}{l}\text { es); U.S. } \\
\text { hiphisal } \\
1850-1880 \\
\text { nd Local } \\
\text { e inventor } \\
\text { sover inve }\end{array}$ & $\begin{array}{l}\text { Census of } \\
\text { 2006); and } \\
\text { and 1900- } \\
\text { Histories). } \\
\text { 's previous } \\
\text { ntion). See }\end{array}$ \\
\hline
\end{tabular}


TABLE 10

REgressions of InVENTOR PRODUCTIVITY AT MAKING CROSSOVER INVENTIONS

\begin{tabular}{|c|c|c|c|c|c|c|}
\hline \multirow[b]{2}{*}{ No. of crossover patents made in entire career } & \multirow[t]{2}{*}{ (1) } & \multirow[b]{2}{*}{$\begin{array}{c}\text { Not move for } \\
\text { entire } \\
\text { patenting }\end{array}$} & \multirow{2}{*}{$\begin{array}{c}\text { (3) } \\
\text { Not move for } \\
\text { entire } \\
\text { patenting } \\
\text { career and } \\
\text { with college }\end{array}$} & \multicolumn{3}{|c|}{$\begin{array}{c}\text { (4) } \\
\text { Not move for entire patenting career and with } \\
\text { college information }\end{array}$} \\
\hline & & & & $\begin{array}{c}\text { All typesof } \\
\text { first patent } \\
\text { applied }\end{array}$ & $\begin{array}{c}\text { First patent } \\
\text { was crossover }\end{array}$ & $\begin{array}{c}\text { First patent } \\
\text { was other }\end{array}$ \\
\hline \multirow[t]{2}{*}{ Constant } & -25.042 & 2.576 & 8.861 & 4.284 & -30.226 & 36.796 \\
\hline & $(2.87)^{* *}$ & $(0.26)$ & $(0.71)$ & $(0.35)$ & $(1.35)$ & $(2.03)^{*}$ \\
\hline \multirow[t]{2}{*}{ Early training was electrician } & 1.160 & 1.338 & 1.182 & 0.887 & 0.977 & 1.241 \\
\hline & $(8.10)^{* *}$ & $(7.92)^{* *}$ & $(4.84)^{* *}$ & $(3.60)^{* *}$ & $(2.89)^{* *}$ & $(2.78)^{* *}$ \\
\hline \multirow[t]{2}{*}{ Early training was other electrical } & 0.128 & 0.183 & -0.116 & -0.365 & -0.145 & 0.017 \\
\hline & $(0.77)$ & $(0.93)$ & $(0.40)$ & $(1.23)$ & $(0.38)$ & $(0.03)$ \\
\hline \multirow[t]{2}{*}{ Early training was in related science } & 0.251 & 0.185 & 0.250 & -0.167 & 0.278 & -0.549 \\
\hline & $(2.08) *$ & (1.30) & $(1.31)$ & $(0.79)$ & $(0.92)$ & (1.93) \\
\hline \multirow[t]{2}{*}{ Early training was other technical } & 0.297 & 0.206 & -0.052 & 0.120 & 0.170 & 0.187 \\
\hline & $(2.29) *$ & (1.31) & $(0.23)$ & $(0.54)$ & $(0.50)$ & $(0.60)$ \\
\hline \multirow{2}{*}{ ln (no. of core electrical patents per million capita) } & 0.171 & 0.107 & 0.116 & 0.094 & 0.081 & 0.083 \\
\hline & $(6.28)^{* *}$ & $(3.12)^{* *}$ & $(2.46)^{*}$ & $(2.03)^{*}$ & (1.29) & (1.19) \\
\hline \multirow{2}{*}{ ln (no. of overall patents per million capita) } & 0.230 & 0.181 & 0.144 & 0.179 & 0.721 & -0.166 \\
\hline & $(2.82)^{* *}$ & (1.66) & (1.16) & (1.46) & $(2.69)^{* *}$ & (1.09) \\
\hline \multirow[t]{2}{*}{ ln (no. of telegraph operators per thousand capita) } & -0.178 & -0.193 & -0.117 & -0.065 & 0.221 & -0.279 \\
\hline & $(2.40)^{*}$ & (1.56) & $(1.00)$ & $(0.57)$ & $(0.64)$ & (1.93) \\
\hline \multirow[t]{2}{*}{ ln (electric utilization per thousand capita) } & -0.342 & -0.236 & -0.166 & -0.176 & -0.376 & 0.038 \\
\hline & $(7.53)^{* *}$ & $(3.61)^{* *}$ & $(1.92)$ & $(2.07)^{*}$ & $(2.92)^{* *}$ & $(0.28)$ \\
\hline \multirow[t]{2}{*}{ Birth year } & 0.013 & -0.001 & -0.005 & -0.002 & 0.015 & -0.019 \\
\hline & $(2.87)^{* *}$ & $(0.28)$ & $(0.70)$ & $(0.35)$ & (1.27) & $(1.97)^{*}$ \\
\hline \multirow[t]{2}{*}{1910 year dummy } & 0.825 & 0.936 & 0.673 & 0.507 & 0.842 & 0.308 \\
\hline & $(5.80)^{* *}$ & $(4.77)^{* *}$ & $(2.59)^{* *}$ & $(1.98)^{*}$ & $(2.44)^{*}$ & $(0.76)$ \\
\hline \multirow[t]{2}{*}{ Went to college } & & & & 0.783 & 0.556 & 0.932 \\
\hline & & & & $(4.25)^{* *}$ & $(2.04)^{*}$ & $(3.59)^{* *}$ \\
\hline Observations & 646 & 433 & 218 & 218 & 120 & 83 \\
\hline
\end{tabular}

Sources and Notes: Standard errors are clustered by states. Also, see Table 9. 